\title{
Nickel Complexes in C-P Bond Formation
}

\author{
Almaz A. Zagidullin (1), Il'yas F. Sakhapov, Vasili A. Miluykov (1) and Dmitry G. Yakhvarov *(i) \\ Arbuzov Institute of Organic and Physical Chemistry, FRC Kazan Scientific Center, Russian Academy of Sciences, \\ Arbuzov Str. 8, 420088 Kazan, Russia; zagidullin@iopc.ru (A.A.Z.); sakhapovilyas@mail.ru (I.F.S.); \\ miluykov@iopc.ru (V.A.M.) \\ * Correspondence: yakhvar@iopc.ru; Tel.: +7-(843)-273-2253
}

Citation: Zagidullin, A.A.; Sakhapov, I.F.; Miluykov, V.A.; Yakhvarov, D.G. Nickel Complexes in C-P Bond Formation. Molecules 2021, 26, 5283. https://doi.org/10.3390/ molecules 26175283

\section{Academic Editors: Viktor}

O. Iaroshenko and Satenik Satenik Mkrtchyan

Received: 26 July 2021

Accepted: 26 August 2021

Published: 31 August 2021

Publisher's Note: MDPI stays neutral with regard to jurisdictional claims in published maps and institutional affiliations.

Copyright: (c) 2021 by the authors. Licensee MDPI, Basel, Switzerland. This article is an open access article distributed under the terms and conditions of the Creative Commons Attribution (CC BY) license (https:// creativecommons.org/licenses/by/ $4.0 /)$.
Abstract: This review is a comprehensive account of reactions with the participation of nickel complexes that result in the formation of carbon-phosphorus (C-P) bonds. The catalytic and noncatalytic reactions with the participation of nickel complexes as the catalysts and the reagents are described. The various classes of starting compounds and the products formed are discussed individually. The several putative mechanisms of the nickel catalysed reactions are also included, thereby providing insights into both the synthetic and the mechanistic aspects of this phosphorus chemistry.

Keywords: nickel complexes; organophosphorus compounds; catalysis; organic and inorganic phosphanes; phosphorylation; electrochemistry

\section{Introduction}

Taking into account the use of organophosphorus compounds in organic synthesis and homogeneous catalysis, materials chemistry, agrochemical crop protection and pharmaceutical discovery, new methods for their synthesis hold particular significance [1-5]. Traditional methods to construct carbon-phosphorus $(\mathrm{C}-\mathrm{P})$ bonds-a key step in the synthesis of organophosphorus compounds-such as radical methods, anionic methods and the Arbuzov, Pudovik, Michaelis, Kabachnik-Fields, Abramov reactions are well known. These classical methodologies suffer from safety problems and limited scope, lack of selectivity and the use of protective groups that lead to additional stages of synthesis. Therefore, there has been growing interest in the development of transition-metal-catalyzed $\mathrm{C}-\mathrm{P}$ bond construction as one of the most attractive method due to the safety, selectivity, high functional group tolerance and 100\% atom economy provided by this approach [6-9].

Among the wide range of transition metals used for $\mathrm{C}-\mathrm{P}$ bond construction, our attention has focused on nickel complexes. The development of organonickel chemistry has led to the discovery of several remarkable catalytic systems with excellent practical applications [10-12]. Actually, homogeneous Ni catalysis is currently experiencing a period of growing interest, resulting in numerous fascinating applications in synthetic organic and organophosphorus chemistry. Catalytic cycles with organonickel complexes as intermediates in many cases demonstrate high efficiency and include non-reactive organic and phosphorus substrates, but it is difficult to predict and control all reaction pathways [13]. From another point of view, cost-effectiveness is the undisputed driving force and great advantage behind the choice of nickel for catalytic applications, because comparing the cost of catalyst precursors for nickel and other noble metals shows a dramatic difference.

This review provides an overview of the nickel-catalyzed synthesis of phosphanes, phosphonium salts, phosphane oxides and phosphorus acid derivatives. This review focuses on the latest advances in applications of nickel complexes as an effective catalyst in C-P bond formation, some aspects of the reaction mechanism and important advances in the asymmetric synthesis of organophosphorus compounds. 


\section{Synthesis of Tricoordinated Organophosphorus Compounds}

\subsection{Synthesis of Phosphanes Using Phosphane Chlorides}

Phosphane chlorides are a useful class of $P$-coupling partners because the commonly used secondary phosphanes, their oxides or borane complexes are pyrophoric, require an additional reduction step or are incompatible with other functional groups. Cristau et al. reported initial efforts in the Ni-catalyzed cross-coupling of diphenylphosphane chloride with arylbromides [14]. Since the reaction yielded a mixture of phosphonium salts and triphenylphosphane oxides after workup, it has been evaluated that it is not synthetically useful.

An interesting version of cross-coupling with diphenylphosphane chloride catalyzed by $\mathrm{NiCl}_{2}$ (dppe) (dppe-1,2-bis(diphenylphosphano)ethane) in the presence of stoichiometric amounts of metallic $\mathrm{Zn}$ was reported in [15] (Figure 1). In this reaction, zinc performs two functions: it reduces $\mathrm{Ni}(\mathrm{II})$ to $\mathrm{Ni}(0)$ and gives rise to zinc phosphide $\mathrm{Ph}_{2} \mathrm{PZnCl}$, which reacts with ArylX. This methodology represents a convenient procedure for the preparation of different tertiary phosphanes, including the coupling of sterically hindered aryl halides or sulfonates that contain ortho-substituents as well as amide groups in the substrates. It should be noted that aryltrifluoromethanesulfonates provide higher yields (46-95\%) than similar bromides.<smiles>[R]C1=CCCCC1</smiles>
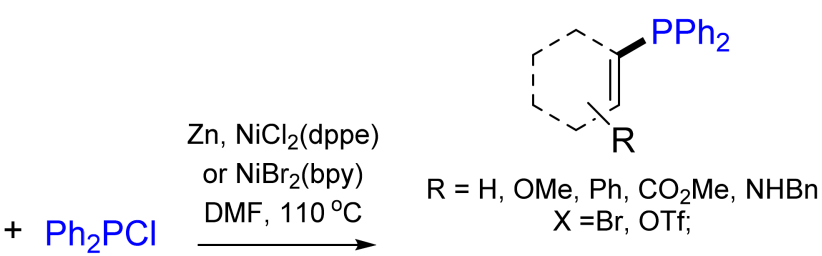<smiles>[R]c1cccc(Br)c1</smiles><smiles>[R]c1cccc(P)c1</smiles>

$\mathrm{R}=\mathrm{CF}_{3}, \mathrm{CN}, \mathrm{CO}_{2} \mathrm{Et}, \mathrm{MeO}, \mathrm{CHO}, \mathrm{Ac}$

Figure 1. Nickel-catalyzed cross-coupling in the presence of zinc.

Later, using this methodology, functionalized triarylphosphanes were obtained with good yields (55-86\%) in a one-step reaction of an equimolar mixture of chlorodiphenylphosphane and aromatic bromides in NMP or DMF at $110{ }^{\circ} \mathrm{C}$ in the presence of zinc dust as a cheap reductant and $\mathrm{NiBr}_{2}$ (bpy) (bpy-2,2'-bipyridine) as an efficient catalyst [16] (Figure 1). The main features of this versatile method are the simplicity of the reaction conditions and the compatibility with various functional groups.

Since then, (trimethylsilyl)diphenylphosphane was also employed as the phosphorus coupling partner. The optimized conditions for the Ni-catalyzed C-P cross-coupling reaction included $\mathrm{NiCl}_{2}\left(\mathrm{PPh}_{3}\right)_{2}$ as the catalyst, ${ }^{\mathrm{t}} \mathrm{BuOK}$ as the base and $\mathrm{Me}_{3} \mathrm{SiPPh}_{2}$ as the phosphane reagent at $90{ }^{\circ} \mathrm{C}$ [17] (Figure 2).

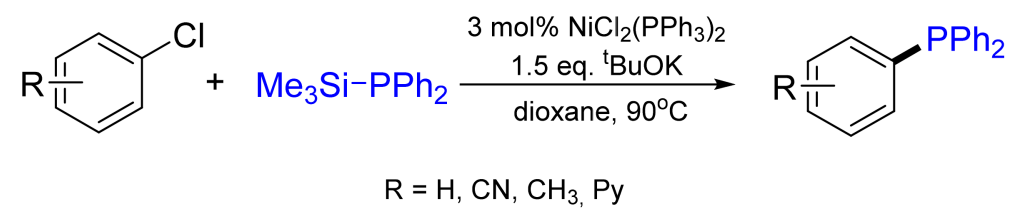

Figure 2. Nickel-catalyzed cross-coupling with (trimethylsilyl)diphenylphosphane.

Nickel- as well as palladium- and copper-catalyzed couplings of terminal alkynes with chlorophosphanes were developed later [18,19]. The Ni-catalyzed coupling of diarylchloro-, 
dialkylchloro-, aryldichloro- and trichlorophosphane $\left(\mathrm{PCl}_{3}\right)$ with terminal acetylenes is a smooth transformation leading to a corresponding C-P coupling product in high yield (Figure 3). It should be noted that the couplings of aryldichlorophosphanes and trichlorophosphane $\left(\mathrm{PCl}_{3}\right)$ are not selective, resulting in a mixture of mono-, di- and trisubstituted products.

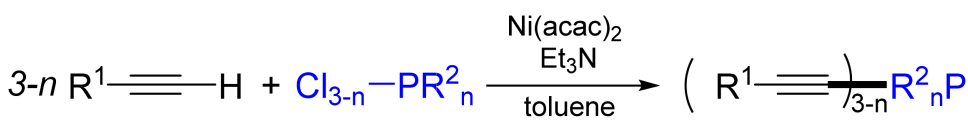

$$
\begin{aligned}
& \mathrm{R}^{1}=\mathrm{Ph}, \mathrm{p}-\mathrm{Tol}, \mathrm{Pr}, \mathrm{Am},{ }^{\mathrm{t}} \mathrm{Bu} ; \mathrm{R}^{2}=\mathrm{Ph},{ }^{\mathrm{i}} \mathrm{Pr}, \mathrm{Bu}
\end{aligned}
$$

Figure 3. General scheme for a nickel-catalyzed cross-coupling reaction with terminal alkynes.

From the mechanistic point of view, the authors claim the reaction to be a heteroanalogue of the Sonogashira cross-coupling [20]. The initial step of the catalytic cycle is the oxidative addition of the chlorophosphane to the Ni complex, forming a Ni-phosphido complex. Subsequent ligand exchange from chloride to acetylide gives a Ni-organic sigma complex, which then liberates phosphanoalkyne after reductive elimination (Figure 4).

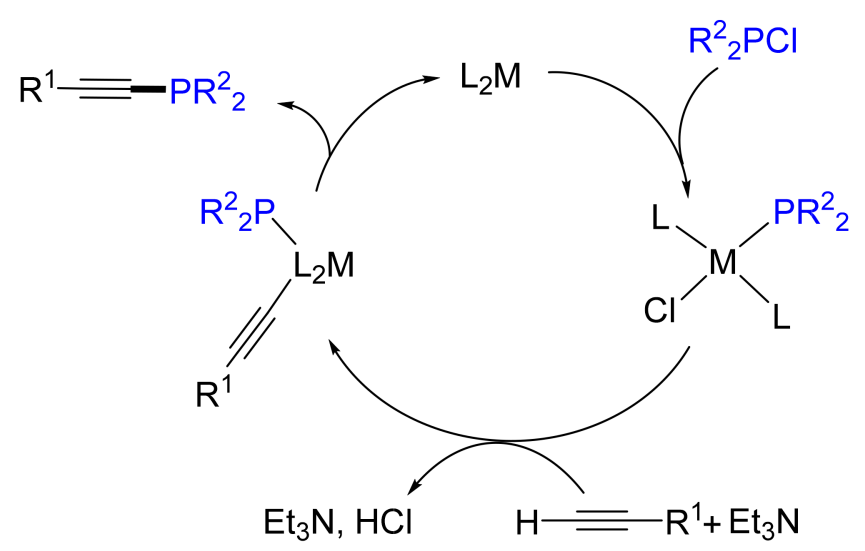

Figure 4. Proposed mechanism for the nickel- and palladium-catalyzed C(sp)-P cross-coupling $(\mathrm{M}=\mathrm{Ni}, \mathrm{Pd})$.

\subsection{Arylation and Vinylation of Secondary and Primary Phosphanes}

The first example of secondary phosphanes used in transition metal-catalyzed crosscoupling reactions was demonstrated by Cristau et al., who explored the arylation of diphenylphosphane $\mathrm{Ph}_{2} \mathrm{PH}$ by aryl bromides in the presence of $\mathrm{NiBr}_{2}$ salt [14]. Upon the reaction of bromobenzene with diphenylphosphane in the presence of $\mathrm{NiBr}_{2}$, a mixture of triphenylphosphane (31\%) and tetraphenylphosphonium bromide (19\%) salt was obtained (Figure 5).

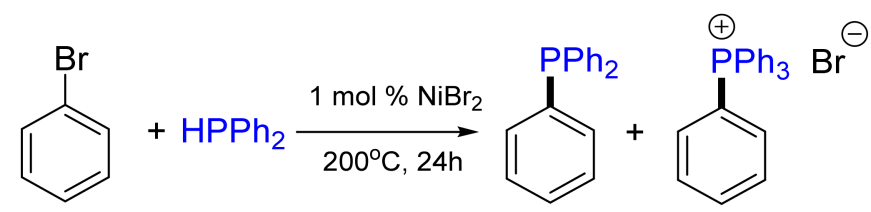

Figure 5. Nickel-catalyzed arylation of diphenylphosphane.

Later, Shulyupin et al. further broadened the synthetic applicability by employing $\left(\mathrm{Ph}_{3} \mathrm{P}\right)_{2} \mathrm{NiCl}_{2}$ or $\mathrm{Ni}$ (acac) $)_{2}$ (acac-acetylacetone) as efficient catalyst precursors in the phosphination of vinyl bromides and chlorides with diphenylphosphane (Figure 6) [21]. The procedure uses a combination of up to $1 \mathrm{~mol} \%$ of Ni complexes, triethylamine and DMF as a solvent, leading to products with $75-96 \%$ yields. The double bond geometry of the vinyl halides was retained under the reaction conditions. 


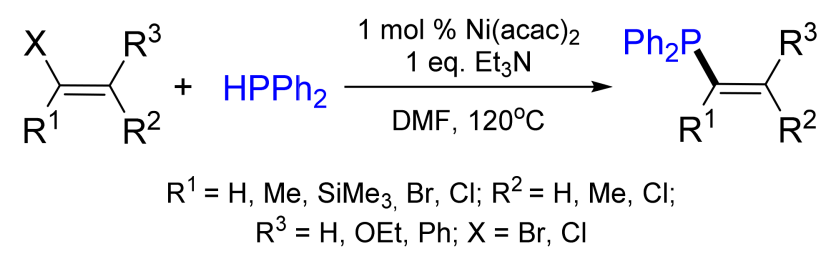

Figure 6. Nickel-catalyzed phosphination of vinyl bromides.

Functionalized vinylphosphanes containing alkoxy- or amino- groups were synthesized by the reaction of diphenylphosphane or its trimethylsilyl derivative with the corresponding alkenyl bromides or chlorides under catalysis by nickel complexes. Ni complexes turned out to be more efficient than Pd complexes in reactions with less active alkenyl halides, such as 2-bromobutene and 1-bromovinylsilane [22]. Likewise, two diphenylphosphano groups were introduced into 1 and 4 positions of 1,4-diiodo-butadienes with 90-95\% yields [23] (Figure 7).

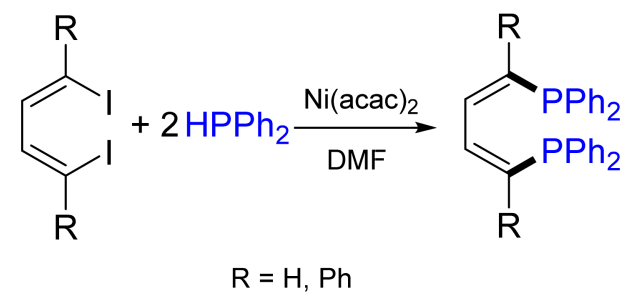

Figure 7. Nickel-catalyzed phosphination of vinyl iodides.

A striking example of a Ni-catalyzed cross-coupling was developed by Cai et al. for the synthesis of BINAP [24], one of the most efficient and successful chiral ligands, which was synthesized for the first time by the Noyori group in the early 1980s. These authors anticipated the use of a Ni catalyst, instead of a Pd catalyst, to be more promising since the former binds to BINAP weaker than any other transition metal of the second or third row. Thus, catalyst poisoning was prevented. After the initial optimization of the reaction conditions, BINAP was synthesized without racemization. The best yield of $77 \%$ was obtained by $\mathrm{NiCl}_{2}$ (dppe) cross-coupling of aryltriflate and diphenylphosphane in DMF in the presence of DABCO as a base [25], while other systems did not promote the reaction or led to side or oxidation reactions (Figure 8). Fortunately, Cai's method is not restricted to diarylphosphanes, since dialkylphosphanes were also used in this reaction [26]. In addition, Wills and co-workers reported that, in some cases, the addition of zinc dust improves the yield [27].

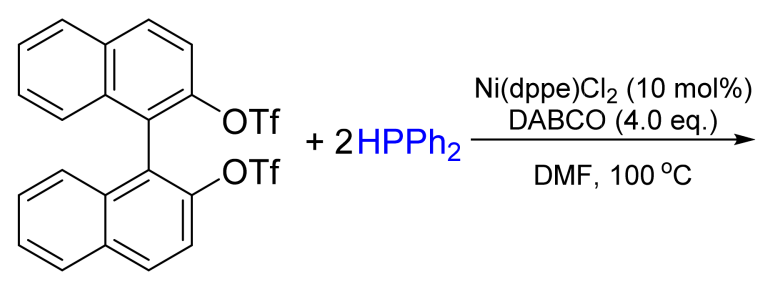<smiles>Pc1ccc2ccccc2c1-c1c(P)ccc2ccccc12</smiles>

Figure 8. $\mathrm{Ni}(\mathrm{dppe}) \mathrm{Cl}_{2}$-catalyzed BINAP synthesis.

Several research groups have adopted the Ni-catalyzed cross-coupling protocol developed by Cai et al. for the synthesis of a wide variety of chiral phosphanes: axially chiral Quinazolinap ligand [28,29], P-stereogenic BINAP [30] and other binaphthyl-based phosphane and phosphite ligands [31]. Figure 9 shows selected examples, such as steroidal [32] and pyrazinylnaphthyl derivatives of BINAP [33], PINAPs [34,35], or fluoroalkyl-tagged binaphthyls [36,37]. 
<smiles>CC12CCCC1c1ccc(P)c(-c3c(-c4ccccc4)ccc4c5c(ccc34)C3CCCC3(C)CC5)c1CC2</smiles><smiles>Cc1cnc(C)c(-c2c(P)ccc3ccccc23)c1</smiles>

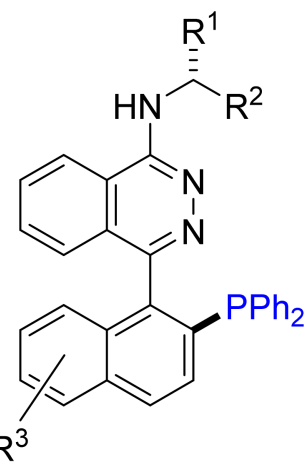<smiles>[R]c1ccc2c(-c3c(-c4ccccc4)ccc4cc([R])ccc34)c(-c3ccccc3)ccc2c1</smiles>

Figure 9. Selected examples of phosphane ligands obtained by Cai's method.

Recently, Zhao et al. disclosed a method for the cross-coupling of various aryl bromides with diphenylphosphane in the absence of external reductants and supporting ligands (Figure 10) [38]. The reaction gave a mixture of phosphanes and phosphane oxides with $64-99 \%$ yields. Several functional groups (ester, ether, ketone and cyano groups) remained intact under the conditions.

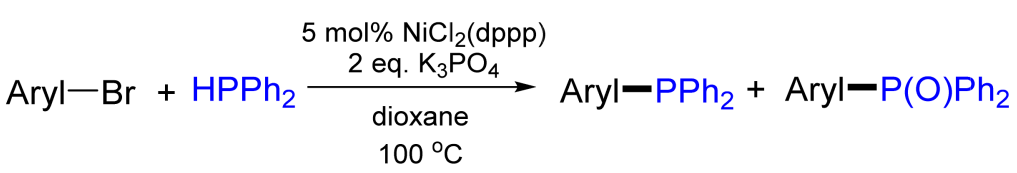

Figure 10. Nickel-catalyzed cross-coupling between aryl bromides and diphenylphosphane.

In addition to the above-mentioned methods, an electrochemically promoted nickel catalysed processes were also developed [39,40]. Organonickel sigma-complexes have been found as efficient key intermediates in various Ni-catalyzed C-C coupling reactions [41], electrocatalytic processes and C-P bond formation with participation of unfunctionalized organic arylhalides with elemental (white) phosphorus $\mathrm{P}_{4}$ [42], chlorophosphanes or various primary and secondary phosphanes (Figure 11) [43,44].

\subsection{Hydrophosphination Reactions of Alkenes and Alkynes}

Hydrophosphination reactions involve the addition of $\mathrm{P}-\mathrm{H}$ to an unsaturated $\mathrm{C}-\mathrm{C}$ bond and have gained great interest as an alternative to the classical phosphane syntheses involving a substitution that is incompatible with certain functional groups. In this reaction, phosphanes, silylphosphanes or phosphane-borane complexes are used as phosphinating agents to react with inactivated or activated alkenes, dienes and alkynes. Moreover, the addition of $\mathrm{P}-\mathrm{H}$ to an unsaturated $\mathrm{C}-\mathrm{C}$ bond is more efficient than substitution reactions when considering atom efficiency that makes it greener and more economical. 


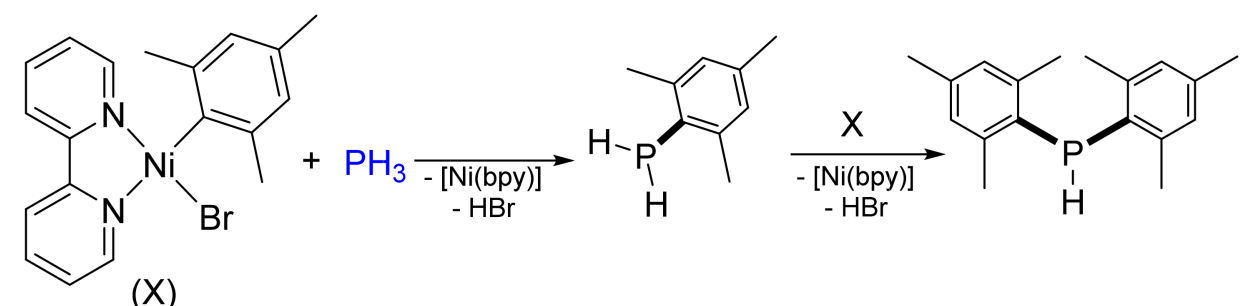

$(\mathrm{X})$

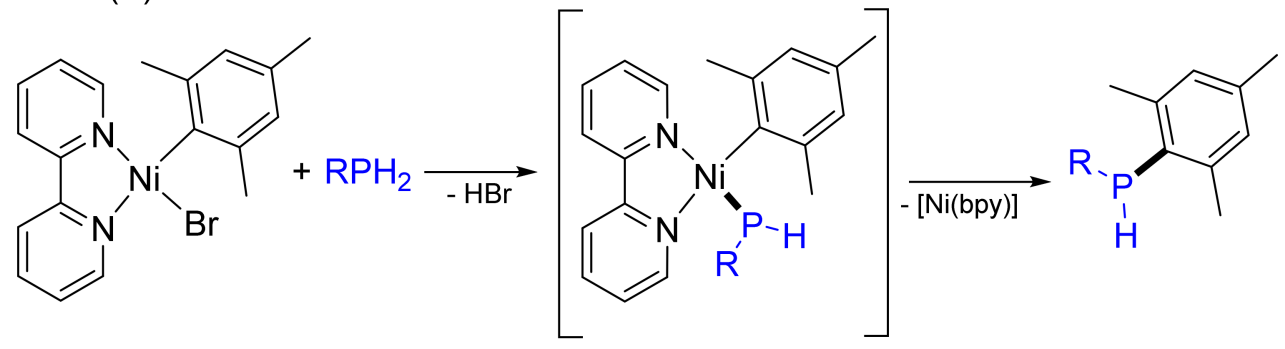

$\mathrm{R}=\mathrm{Ph}, \mathrm{Mes},{ }^{\mathrm{i}} \mathrm{Bu}, \mathrm{Cy}$

Figure 11. Reactivity of organonickel sigma-complexes with phosphanes.

In recent years, great progress has been made in metal-complex-catalyzed hydrophosphination reactions $[9,45]$. It should be noted that reactions of P-H and P-E compounds with alkynes in the presence of transition metal complexes occur preferentially as syn-addition. It was shown that hydrophosphination reactions catalyzed by Ni-based complexes proceed more efficiently and allow inactivated alkenes to be employed [46-49]. Shulupin et al. first reported hydrophosphination with high yields up to $99 \%$ of weakly activated aryl olefins and their heterocyclic analogues in the presence of $\mathrm{Ni}(0)$ phosphite complexes (Figure 12) [50].

$$
\begin{aligned}
& \text { (Het)Aryl- } \mathrm{CH}=\mathrm{CH}_{2}+\mathrm{HPPh}_{2} \frac{\mathrm{Ni}\left[\mathrm{P}(\mathrm{OEt})_{3}\right]_{4} \mathrm{C}_{6} \mathrm{H}_{6}}{50-130^{\circ} \mathrm{C}}(\mathrm{Het}) \operatorname{Aryl}-\mathrm{CH}_{2}-\mathrm{CH}_{2}-\mathrm{PPh}_{2} \\
& \text { Aryl }=\mathrm{Ph}, 4-\mathrm{MeOC}_{6} \mathrm{H}_{4}, 2-\mathrm{MeOC}_{6} \mathrm{H}_{4}, 4-\mathrm{MeC}_{6} \mathrm{H}_{4}, 4-\mathrm{ClC}_{6} \mathrm{H}_{4} \\
& \text { Het }=4 \text {-pyridyl, 5-methyl-2-pyridyl, 2-pyridyl. }
\end{aligned}
$$

Figure 12. Hydrophosphination of weakly activated olefins and their heterocycle-containing analogues.

The reaction is regioselective: the only product is the corresponding $\beta$-phosphorylated adduct. The fact that no $\alpha$-adduct is formed in the addition of $\mathrm{Ph}_{2} \mathrm{PH}$ to styrenes and vinylpyridines allows the formation of $\pi$-allyl intermediates to be excluded. A probable catalytic cycle includes the oxidative addition of phosphane to $\mathrm{Ni}(0)$ with the formation of a hydride phosphide complex, alkene insertion into the $\mathrm{Ni}-\mathrm{H}$ bond and subsequent reductive elimination (Figure 13). Later, Ganushevich et al. characterized, for the first time, the product of an oxidative addition of primary phosphane to a nickel(0) complex. The terminal phosphanido hydride nickel complex, $[\mathrm{NiH}\{\mathrm{P}(\mathrm{Dmp})(\mathrm{H})\}(\mathrm{dtbpe})]$, where Dmp2,6-dimesitylphenyl and dtbpe-1,2-bis(di-tert-butylphosphino)ethane, has been formed in this process [51-53]. 


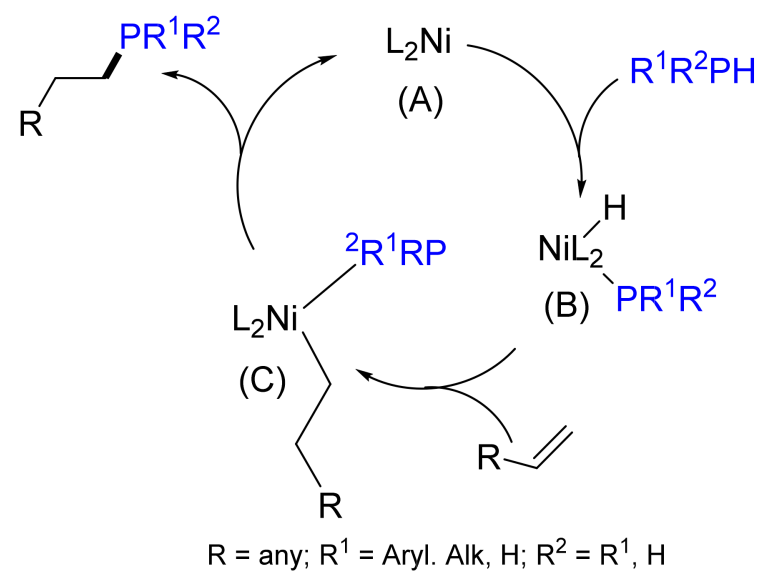

Figure 13. Mechanism of a Ni-catalyzed hydrophosphination of alkenes.

Chiral metal complexes have been used to promote and control the asymmetric $\mathrm{P}-\mathrm{H}$ addition reaction. A chiral pincer bisphosphane Ni complex was used in the first highly enantioselective catalytic synthesis of $P$-stereogenic secondary phosphane-boranes by the asymmetric hydrophosphination of electron-deficient alkenes with phenylphosphane. Various $P$-stereogenic secondary phosphane-boranes were obtained in $57-92 \%$ yields with up to $99 \%$ ee [54]. The Togni group developed the asymmetric hydrophosphination of vinyl nitriles catalyzed by a dicationic Ni-based complex yielding the desired phosphane product with $32-94 \%$ ee $[55,56]$ (Figure 14).

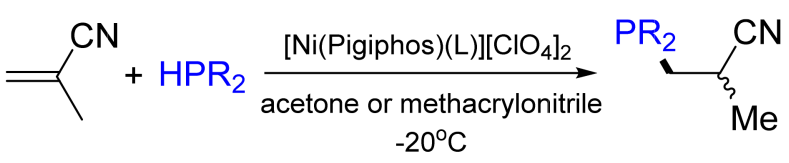

$\mathrm{R}=\mathrm{Ph} ; \mathrm{Cy} ;{ }^{\mathrm{i}} \mathrm{Pr} ; \mathrm{Ad} ;{ }^{\mathrm{t}} \mathrm{Bu} ; \mathrm{EtMe}_{2} \mathrm{C}$

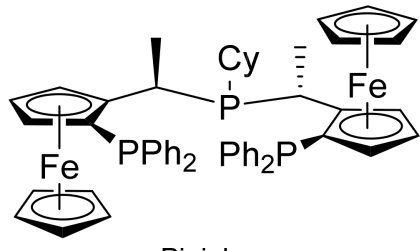

Pigiphos

Figure 14. Ni-catalyzed asymmetric hydrophosphination of methacrylonitrile.

The addition of $\mathrm{P}-\mathrm{H}$ to a triple bond is a highly desirable method when considering the principles of atom economy. The first example of the hydrophosphination of terminal and internal alkynes, catalyzed by $\mathrm{Pd}$ and Ni complexes, was reported by Kazankova et al. (Figure 15) [57]. The regioselectivity was strongly dependent on the catalytic precursor and alkyne nature. In the presence of $\operatorname{Pd}(0)$ and $\mathrm{Ni}(0)$ complexes, the $\beta$-adduct was formed as the major product. By contrast, $\mathrm{Pd}(\mathrm{II})$ and $\mathrm{Ni}(\mathrm{II})$ complexes mainly gave rise to the $\alpha$-adduct $(\alpha: \beta=95: 5)$ [58]. The different selectivity in the reactions catalyzed by $\mathrm{Pd}(0) / \mathrm{Ni}(0)$ complexes and $\mathrm{Pd}(\mathrm{Ni}) \mathrm{X}_{2}$ is explained by the formation of catalytic amounts of $\mathrm{HX}$ (HOAc or $\mathrm{HBr}$ ) in situ, which initiate the second catalytic cycle. The Ni-based catalyst was more effective than the Pd-based catalyst, and the reaction proceeded at lower temperatures. The relative reactivity of the metal complexes in the hydrophosphination of alkynes was studied theoretically by Ananikov et al., and it decreased in the order of $\mathrm{Ni}>\mathrm{Pd}>\mathrm{Rh}>$ Pt. [59]. The estimated relative reactivity order of the studied metals implies that nickel can not only be a cost-economic replacement of $\mathrm{Pd}$, but also superior in terms of catalytic efficiency. In the reaction of diphenylphosphane with tert-butylacetylene, the corresponding $\beta$-adduct with $95 \%$ yield is formed as the only product for steric reasons. The addition of diphenylphosphane to other alkylacetylenes is characterized by lower selectivity, with both regio- and stereoselectivity strongly dependent on the reaction conditions. 


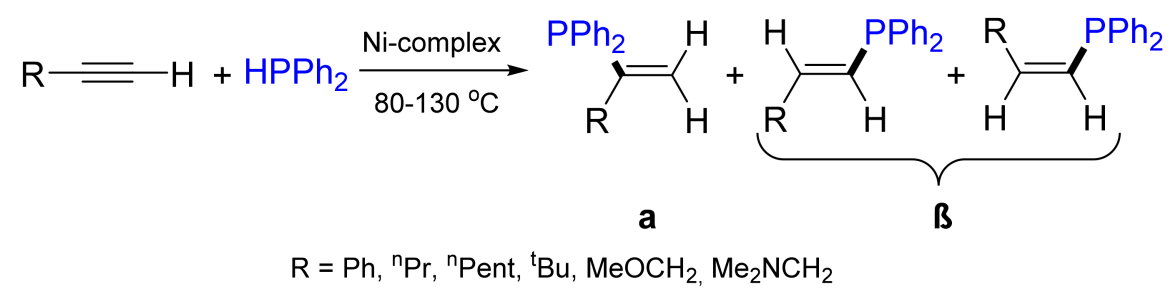

Figure 15. Nickel-catalyzed addition of $\mathrm{HPPh}_{2}$ to alkynes.

Later, an efficient NCC pincer Ni(II)-catalyzed hydrophosphination of nitroalkenes with $\mathrm{HPPH}_{2}$ was developed. After the optimization of reaction conditions, (hetero)aromatic and aliphatic nitroalkenes were well tolerated, irrespective of electronic effects, to provide the products in up to $99 \%$ yield [60]. In addition to P(III) phosphanes, Montchamp and co-workers produced vinyl- $H$-phosphinates from alkynes and alkyl phosphinates using only 2-3 mol\% $\mathrm{NiCl}_{2}$ [61]. Ananikov et al. have shown the Markovnikov-selective phosphorylation of internal and terminal alkynes using a range of phosphites in the presence of catalytic amounts of $\mathrm{Ni}(\mathrm{acac})_{2}$ and 1,2-bis(diphenylphosphano)ethane (dppe) [62]. Han et al. reported that nickel catalysts are more reactive than noble metal catalysts in the catalytic additions of a variety of $\mathrm{P}(\mathrm{O})-\mathrm{H}$ bonds to alkynes (propargyl alcohols, 1-octyne), regioselectively affording both the Markovnikov and the anti-Markovnikov products in high yields (72-96\%) [63]. A related five-coordinated hydrido nickel complex is successfully isolated in the catalysis, which can react readily with an alkyne to give the addition products (Figure 16) [64].

$$
\begin{aligned}
& \mathrm{R}^{1} \equiv+\underset{\substack{\mathrm{I} \\
\mathrm{H}-\mathrm{P}}}{\stackrel{\mathrm{O}}{\equiv}} \underset{20^{\circ} \mathrm{C}}{\stackrel{\mathrm{Ni}(0) \text {-complex }}{\longrightarrow}} \stackrel{\mathrm{R}_{2}(\mathrm{O}) \mathrm{P}}{\mathrm{R}^{1}}+\underset{\mathrm{R}^{1}}{\stackrel{\mathrm{P}(\mathrm{O}) \mathrm{R}_{2}}{\longrightarrow}} \\
& \mathrm{R}=\mathrm{OMe}, \mathrm{O}^{\mathrm{i}} \mathrm{Pr}, \mathrm{Ph} ; \mathrm{R}^{1}={ }^{\mathrm{n}} \mathrm{C}_{6} \mathrm{H}_{13}, \mathrm{Me}_{2} \mathrm{C}(\mathrm{OH})
\end{aligned}
$$

Figure 16. Nickel-catalyzed addition of $\mathrm{R}_{2} \mathrm{P}(\mathrm{O}) \mathrm{H}$ to alkynes.

\section{Synthesis of Tetracoordinated Organophosphorus Compounds}

\subsection{Synthesis of Phosphonium Salts in the Presence of Ni Salts}

The reaction of aryl halides with $\mathrm{PPh}_{3}$ in the presence of $\mathrm{Ni}(\mathrm{II})$ salts is one of the oldest transition metal-catalyzed reactions known to form a C-P bond (Figure 17). Iodobenzene worked best in the reaction (yield up to $90 \%$ ), while the corresponding bromides and chlorides were less reactive and gave lower yields (60-90\%). Electron-donating alkyl, amino or alkoxy groups facilitate the C-P cross-coupling, while electron-withdrawing groups act as strong inhibitors [65]. The reaction is quite common for para- and metasubstituted aryl halides. Although ortho-substituted aryl halides are usually transferred due to the stabilization of the intermediately formed $\mathrm{C}_{\mathrm{sp} 2}-\mathrm{Ni}$ bond, [65] Allen et al. used the directing effect of an imine or a diazo nitrogen atom to perform a chemoselective cross-coupling reaction in the ortho-position under mild conditions [66].

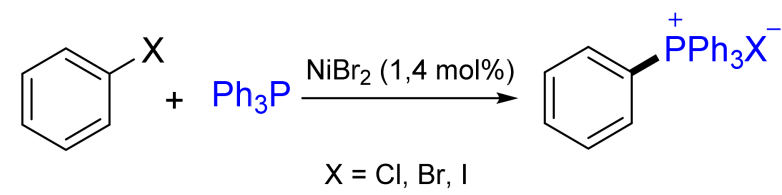

Figure 17. Nickel-catalyzed quaternization of triphenylphosphane.

Thiophene [67], furan [66] and pyrrole [68] halides also served as the substrates or as substituents at the phosphorus atom. In the case of trialkylphosphanes, high temperatures might be problematic for these sensitive substances, so further cross-coupling reactions were successfully performed in refluxing ethanol using $\left(\mathrm{Ph}_{3} \mathrm{P}\right)_{3} \mathrm{Ni}[65,69]$. 
Later, the Charettea group reported a general and efficient Ni-catalyzed cross-coupling reaction between aryl halides (iodides, bromides, chlorides) or triflates and $\mathrm{PPh}_{3}$ generating tetraarylphosphonium salts in good to high yields (63-99\%) (Figure 18). This Ni-catalyzed C-P coupling is conducted in ethylene glycol using a readily available, cheap $\mathrm{NiBr}_{2}$ precatalyst and tolerates different functional groups such as alcohols, amides, ketones, aldehydes, phenols and amines [70].

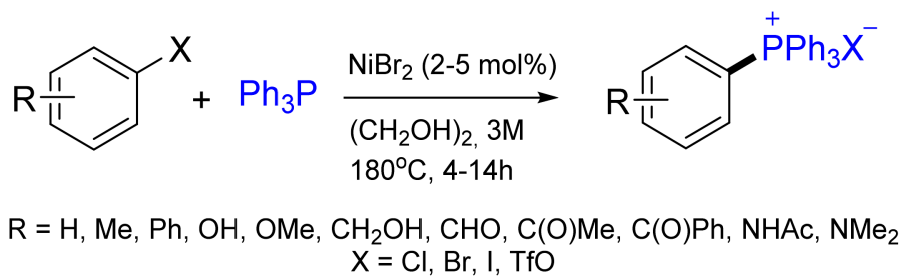

Figure 18. Scope of the Ni-catalyzed C-P coupling.

Additionally, nickel-catalyzed C-P coupling polymerization of commercial aryl dihalides and diphenylphosphane was used for the convenient preparation of tetraarylphosphonium polyelectrolytes. $\mathrm{A} \mathrm{NiBr}_{2}$-based catalyst was effective in $\mathrm{C}-\mathrm{P}$ coupling reactions to yield tetraarylphosphonium polymers with degrees of polymerization up to about 30 [71].

\subsection{Synthesis of Phosphane Oxides by C-P Cross-Coupling}

Transition metal-catalyzed C-P bond formation has been well explored [72]. In the last decade, there have been reports of the use of nickel-based catalysts for the synthesis of phosphane oxides. Yang and co-workers reported the synthesis of diphenylphosphoryl compounds through Ni-catalyzed cross-coupling of diphenylphosphane oxide $\mathrm{Ph}_{2} \mathrm{P}(\mathrm{O}) \mathrm{H}$ with heteroaryl chlorides (Figure 19) [73]. The reactions of various aryl halides with diphenylphosphane oxide were also carried out using the $\mathrm{Ni}(\mathrm{Zn})$ catalyst together with $N$-ligands in water, leading to the formation of diphenylarylphosphane oxides with 75-97\% yields [74].

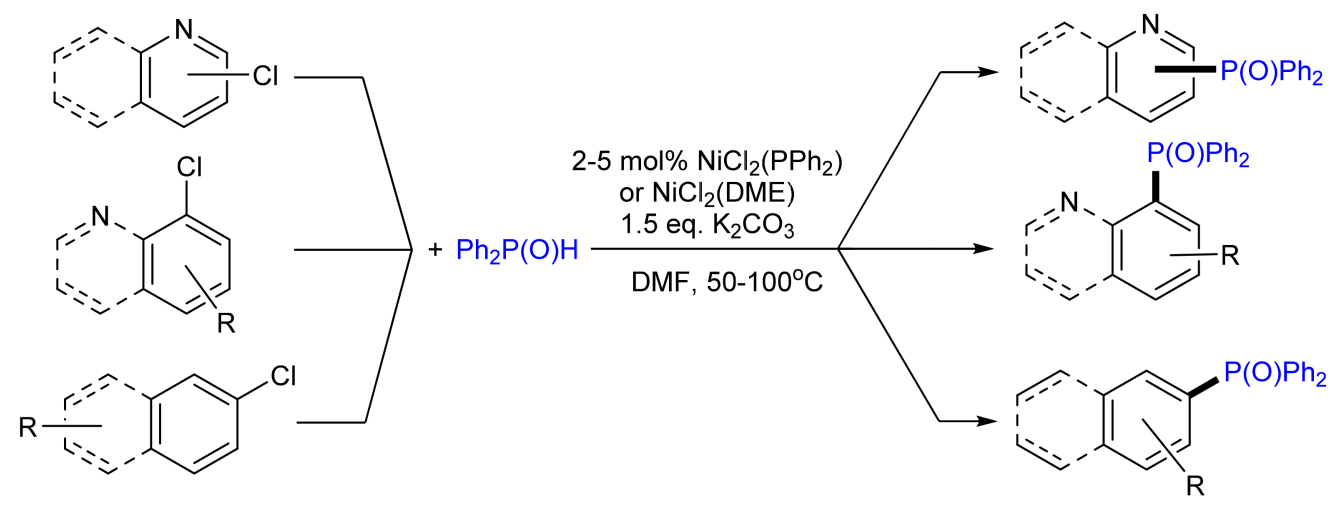

Figure 19. Nickel-catalyzed coupling of aryl chlorides with a diphenyl phosphite.

The Zhao group reported the Ni-catalyzed cross-coupling of functionalized arylboronic acids with $H$-phosphites, $H$-phosphane oxides and $H$-phosphinate esters to give various organophosphorus compounds with good to excellent yields (50-99\%) (Figure 20) [75]. This strategy provided a generalized and substantial tool for the synthesis of triarylphosphane oxides and was the first example of a Ni-catalyzed C-P cross-coupling reaction utilizing $>\mathrm{P}(\mathrm{O}) \mathrm{H}$ substrates and arylboronic acids. 


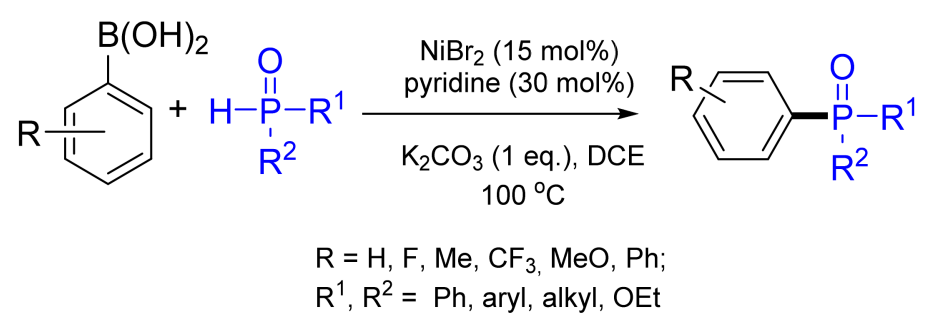

Figure 20. Nickel-catalyzed coupling of arylboronic acids with $P$-nucleophiles.

Later, Liu et al. demonstrated the reaction of 1,1-dibromo-1-alkenes with diphenylphosphane oxide using $\mathrm{NiBr}_{2}$ (bpy) and magnesium in the presence of potassium phosphate at moderate temperatures (Figure 21) [76]. Mechanistic studies show that the reaction involves the «Hirao type» reduction to give alkenyl bromides, which undergo a reaction with diphenylphosphane oxide in the presence of $\mathrm{Ni}(0)$, which can be obtained from $\mathrm{NiBr}_{2}$ by reduction using magnesium.

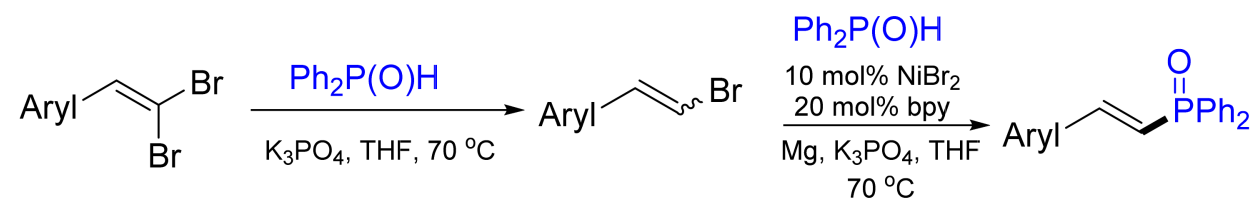

Figure 21. Reaction of alkenyl bromides with diphenylphosphane oxide.

The Xiao group reported the coupling of aryl iodides with diphenyl phosphane oxide at room temperature on the base of nickel and photoredox-based catalytic systems [77]. Photoredox catalysis using $\mathrm{Ru}(\mathrm{bpy})_{3} \mathrm{Cl}_{2}\left(\mathrm{H}_{2} \mathrm{O}\right)_{6}$ with $3 \mathrm{~W}$ blue LED gives the $P$-centered radical, which reacts with the nickel(II)-aryl complex. The reaction takes place at room temperature and tolerates phenol, amide and ether functional groups.

Recently, the decarbonylative coupling of aryl esters with diphenylphosphane oxides in the presence of $\mathrm{Ni}(\mathrm{OAc})_{2}$ was demonstrated by Yamaguchi and co-workers (Figure 22) [78]. The key success of the transformation is the use of the 3,4-bis(dicyclohexylphosphano)thiophene (dcypt) ligand, and the yield was modest to good (48-82\%).

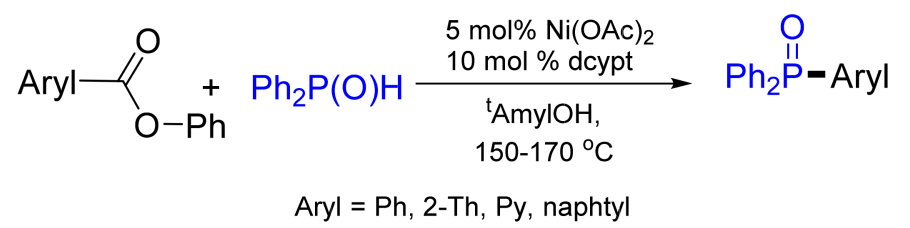

Figure 22. Decarbonylative coupling of esters with phosphane oxide.

A Ni-catalyzed asymmetric allylation of secondary phosphane oxides for the synthesis of tertiary phosphane oxides was realized in the Zhang group with high enantioselectivity (87-95\% ee) (Figure 23) [79]. The protocol represents the first example of synthesizing $P$-stereogenic phosphane oxides by an allylation reaction. The finding of this research expands the applications of Ni-based catalysts and secondary phosphane oxides in the synthesis of $P$-stereogenic phosphanes.

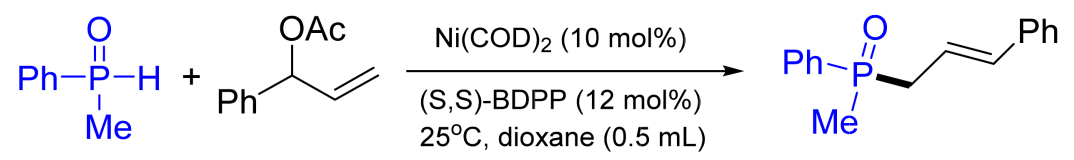

Figure 23. Ni-catalyzed asymmetric allylation of secondary phosphane oxides.

Recently, a visible-light-induced Ni-based catalyst C-P coupling reaction of diarylphosphane oxides with aryl halides has been developed by the Zhu group. The $\mathrm{Ni}(\mathrm{I})$ species and 
chlorine atom radical were generated via the ligand to the metal charge transfer process of $\mathrm{NiCl}_{2}\left(\mathrm{PPh}_{3}\right)_{2}$, which allows the formation of $\mathrm{Ni}(\mathrm{IV})-\mathrm{P}$ species, giving various tertiary phosphane oxides under photocatalyst-free conditions at room temperature in good yields (40-75\%) [80].

Aside from homogeneous systems, effort was made on the development of heterogeneous systems based on $\mathrm{Ni} / \mathrm{CeO}_{2}$ or $\mathrm{Ni} / \mathrm{Al}_{2} \mathrm{O}_{3}$ nanocatalysts for the coupling of aryl iodides or bromides with diphenyl phosphane oxides in the presence of $\mathrm{K}_{2} \mathrm{CO}_{3}$ [81]. The reaction is scalable and the nanocatalyst can be recycled without loss of activity.

\subsection{Synthetic Routes of Phosphinates}

Historically, one of the first methods of non-catalytic C-P bond formation was reactions of alkyl(phenyl)phosphonous esters with aryl halides. One of the first catalytic versions of this reaction was performed with nickel complexes and aryl(alkyl)phosphonous esters with aryl bromides to give various phenyl-arylphosphinates with good to excellent yields (52-82\%) (Figure 24) [82,83].

Aryl- $\mathrm{Br}+\mathrm{PhP}(\mathrm{OEt})_{2} \underset{160^{\circ} \mathrm{C}}{\stackrel{\mathrm{NiX}_{2}}{\longrightarrow}} \mathrm{Ph}-\stackrel{\stackrel{\mathrm{O}}{\text { I }}-\mathrm{O} \text {-OEt }}{\stackrel{\mathrm{I} y l}{ }}$

Figure 24. Ni-catalyzed reaction of phosphonic ethers with aryl bromides.

The carbon-phosphorus cross-coupling of aryl tosylates or mesylates has been accomplished with high yields up to $92 \%$, with ethyl phenylphosphinate using $\mathrm{NiCl}_{2}$ (dppf)/dppf (dppf-1, $1^{\prime}$-bis(diphenylphosphino)ferrocene) at $100{ }^{\circ} \mathrm{C}$ in the presence of diethylisopropylamine (DIPEA) and zinc (Figure 25) [84]. The reaction can also be extended to the coupling of diarylphosphane oxides and diethylphosphonate with aryl sulfonates.

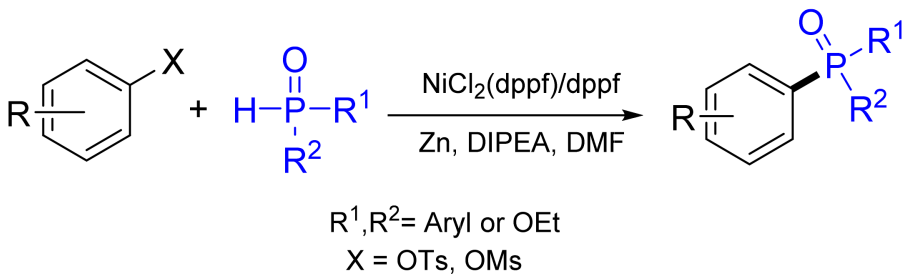

Figure 25. C-P cross-coupling using aryl tosylates or mesylates.

Later, Gao and co-workers achieved the coupling of phenylboronic acid with ethyl phenylphosphinate employing a $\mathrm{NiBr}_{2}$ / pyridine system in the presence of $\mathrm{K}_{2} \mathrm{CO}_{3}(73 \%$ yield) (Figure 26) [75]. The reaction can be extended to the coupling of a series of phosphites and phosphane oxides.

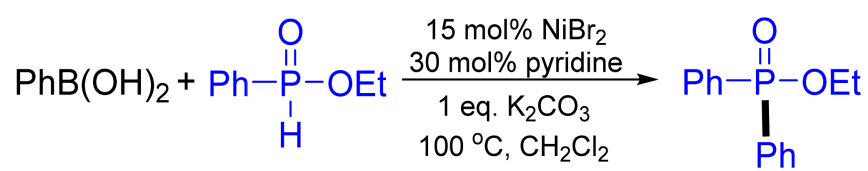

Figure 26. Reaction of phenylboronic acid with ethyl phenylphosphinate.

\subsection{Synthesis of Phosphonates by C-P Cross-Coupling}

\subsubsection{Ni-Catalyzed Phosphonylation with Phosphites}

The reaction of trialkyl phosphites with alkyl halides (Arbuzov reaction) leads to the formation of phosphonates $\mathrm{RP}(\mathrm{O})\left(\mathrm{OR}^{\prime}\right)_{2}$. The Ni-catalyzed procedure using trialkyl phosphites or dialkyl arylphosphonites was described fifty years ago by Tavs et al. and allowed the involvement of aryl and alkenyl halides in this reaction [85]. This work is 
the first example of a transition metal-catalyzed cross-coupling reaction of $\mathrm{C}-\mathrm{P}$ bond formation. The reaction requires harsh conditions $\left(150-200{ }^{\circ} \mathrm{C}\right)$, but the yields of aryl- and alkenylphosphonates are high. The reaction proceeded smoothly using aryl iodides or bromides and phosphite and phosphonite ethyl esters (Figure 27). Exceptions are reactions with ortho-substituted aryl halides, where the yield decreases to 15-40\%. Even alkenyl chlorides, such as $\alpha$ - and $\beta$-chlorostyrenes and vinyl chloride, give rise to alkenylphosphonates in high yields under $\mathrm{NiCl}_{2}$ catalysis [86]. Phosphinites also reacted with good yields [87].

$$
\begin{aligned}
& \text { Aryl-X } \mathrm{X}(\mathrm{OR})_{3} \stackrel{\mathrm{NiCl}_{2} \text { or } \mathrm{NiBr}_{2}}{\underset{150-200^{\circ} \mathrm{C}}{\longrightarrow}} \underset{\mathrm{O}}{\stackrel{\mathrm{O}}{\|}} \stackrel{\mathrm{O}}{\mathrm{O}} \mathrm{O} \\
& \mathrm{R}=\mathrm{Et} ; \mathrm{Pr} \\
& \text { Aryl }=\mathrm{Ph}, \text { Th, naphtyl; } X=\mathrm{Br}, \mathrm{I}
\end{aligned}
$$

Figure 27. Cross-coupling reactions of aryl halides with triethyl phosphites and diethyl phenylphosphonites.

The catalytic arylation of tris(trimethysilyl)phosphite occurs with higher rates (Figure 28) [88]. The treatment of the obtained arylphosphonates with methanol at room temperature gives the corresponding phosphonic acids in quantitative yield.

$$
\left(\mathrm{Me}_{3} \mathrm{SiO}\right)_{3} \mathrm{P}+\mathrm{Aryl}-\mathrm{Br} \underset{\mathrm{NiCl}_{2}, 150^{\circ} \mathrm{C}}{-\mathrm{Me}_{3} \mathrm{SiBr}} \mathrm{Me}_{3} \mathrm{SiO}-\stackrel{\stackrel{\mathrm{II}}{\mathrm{P}}-\mathrm{Aryl}}{\mathrm{OSiMe}_{3}}
$$

Figure 28. The catalytic arylation of tris(trimethylsilyl)phosphite.

The reactions of triethylphosphite with akenylhalides having an alkoxy or diethylamino group in position 1 occurred under milder conditions (Figure 29) [89]. Similar reactions with 2-halovinyl ethers or 2-haloenamines proceeded at a higher temperature, but the yields were also quite high [90].

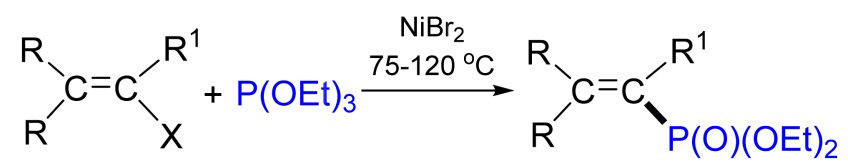

$$
\mathrm{X}=\mathrm{Cl}, \mathrm{Br} ; \mathrm{R}=\mathrm{H}, \mathrm{Me} ; \mathrm{R}^{1}=\mathrm{OR}, \mathrm{NR}_{2}
$$

Figure 29. The reactions of triethylphosphite with alkenyl halides having an alkoxy or diethylamino group.

Another example is the conversion of $(E, E)$-1,3-diiodobutadiene into bis-1,4-(diethoxyphosphanoyl)-1,3-butadiene in high yields [23]. In the above reactions, triethyl phosphite acts as both a phosphorylating and a reducing agent. Balthazor showed that the reaction involves the formation of a $\mathrm{Ni}(0)$ phosphite complex in the presence of a slight excess of the trialkyl phosphite [91]. This phosphite Ni(0) complex undergoes fast oxidative addition with the aryl(vinyl) iodide, followed by slow decomposition to give the quasiphosphonium salt, which is finally transformed into arylphosphonate via classical Arbuzov rearrangement (Figure 30). 


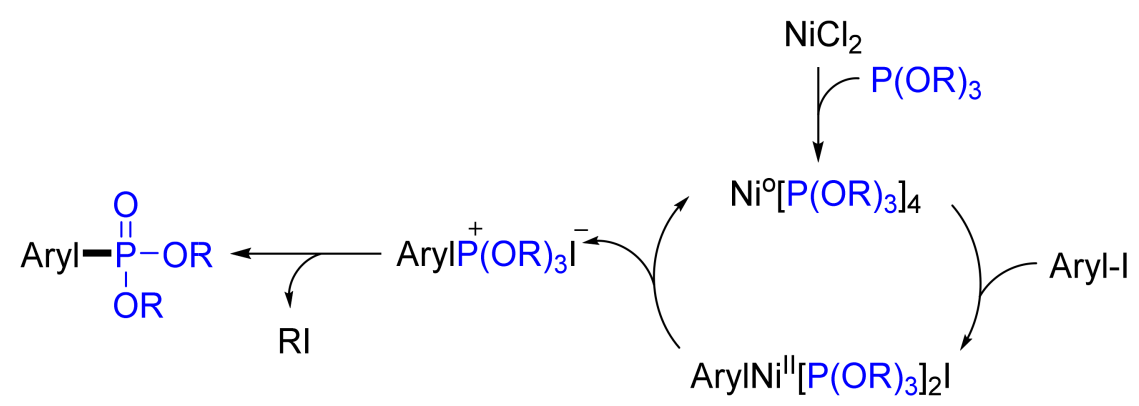

Figure 30. Proposed mechanism for the Ni-catalyzed cross-coupling of trialkyl phosphites with aryl iodides.

Heinicke et al. described the reaction of triethylphosphite with 2-haloanilides in the presence of $\mathrm{NiX}_{2}$ complexes. The resulting o-acylaminophenylphosphonates are useful intermediates in the synthesis of $1 H$-1,3-benzazaphospholes (Figure 31) [92].

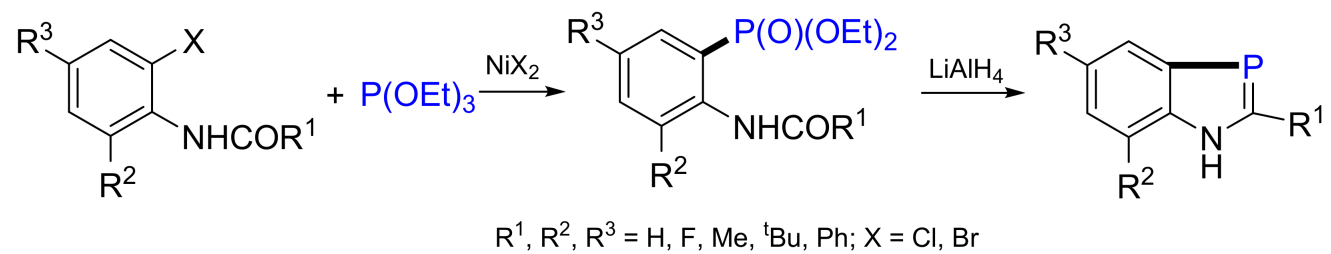

Figure 31. Ni-catalyzed reaction of triethylphosphite with 2-haloanilides.

An efficient method has been developed for the Ni-catalyzed phosphonylation of aryl triflates with triethylphosphite, in which $\mathrm{KBr}$ as an additive promotes the $\mathrm{S}_{\mathrm{N}} 2$ catalytic step (Figure 32). This is the first example of nickel-catalyzed Arbuzov-type reaction of aryl triflates. Most of the substrates showed good reactivity with the use of these catalytic systems and good to high yields (46-95\%) [93].

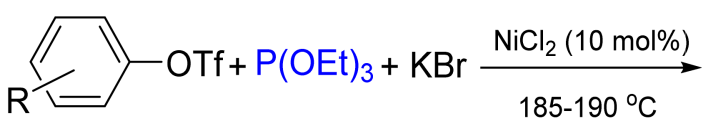<smiles>[R][X]c1ccccc1P(=O)(OCC)OCC</smiles>

$$
\mathrm{R}=\mathrm{H}, \mathrm{Me}, \mathrm{MeO}, \mathrm{Ph}, \mathrm{CO}_{2} \mathrm{Me}, \mathrm{Ac}
$$

Figure 32. Nickel-catalyzed C-P cross-coupling of aryl triflates with triethyl phosphite.

\subsubsection{Phosphonylation by Hirao Reaction}

The Hirao reaction is an alternative synthetic method for obtaining a wide range of phosphonates, which proceeds under milder reaction conditions and with higher yields. It can be considered as a classic example of C-P cross-coupling with the formation of a $\mathrm{C}_{\mathrm{sp} 2}-\mathrm{P}$ bond.

In the 1980s, Hirao et al. reported the first Pd-catalyzed cross-coupling reaction of dialkyl phosphites with aryl and vinyl bromides, resulting in dialkyl arylphosphonates and dialkyl vinylphosphonates, respectively [94]. Later, reactions of allyl acetates and allyl carbonates with dialkyl phosphites were investigated under Ni catalysis in the presence of bis(trimethylsilyl)acetamide (BSA) as a base $[95,96]$. A direct comparison of nickeland palladium-catalyzed cross-coupling for vinyl halides was reported by Beletskaya and co-workers [90]. Aryl and vinyl iodides as well as bromides reacted smoothly under these reaction conditions, while the corresponding chlorides were unreactive.

Nowadays, nickel catalysis is often applied in Hirao C-P cross-coupling reactions, and a range of organic and organometallic compounds including organohalides, alcohol or phenol derivatives [97-100], aryl, benzyl or allyl ammonium salts [101], sulfides [102] and aryl nitriles $[103,104]$ have been employed as the carbon coupling partners. Reductive 
procedures involve $\mathrm{Ni}$ (II) salts together with $\mathrm{Zn} / \mathrm{Mg}$ as the reductant or without reductive agents or $\mathrm{Ni}(0)(\mathrm{cod})_{2}$ as the catalyst precursor [75].

Han and co-workers extended the substrate scope to aryl bromides and chlorides with dimethylphosphite and diphenylphosphane oxide using $\mathrm{NiCl}_{2}(\mathrm{dppp}$ ) (where $\mathrm{dppp}-1,3-$ bis(diphenylphosphano)propane) in the presence of potassium phosphite $\mathrm{K}_{3} \mathrm{PO}_{4}$, leading to phosphonates with 50-96\% yields (Figure 33) [38].

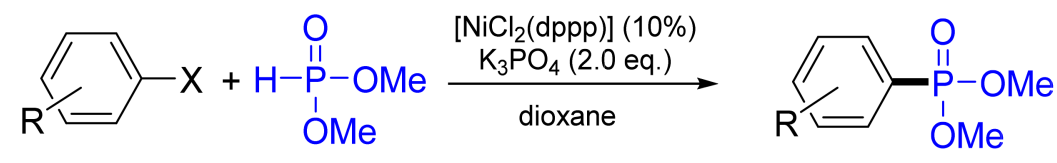

$\mathrm{R}=\mathrm{H}, \mathrm{MeO}, \mathrm{Ac}, \mathrm{CO}_{2} \mathrm{Me}, \mathrm{CN} ; \mathrm{X}=\mathrm{Cl}, \mathrm{Br}$

Figure 33. Cross-coupling of dimethyl phosphite with various aryl halides.

Challenging phenol derivatives could also be involved in C-P coupling reactions after converting the hydroxyl function to a better leaving group by reaction with bromotripyrrolidinophosphonium hexafluorophosphate (PyBroP) (Figure 34) [105]. The method allows the $\mathrm{C}-\mathrm{P}$ cross-coupling to be carried out in a one-pot procedure without the isolation of an activated phenol intermediate.

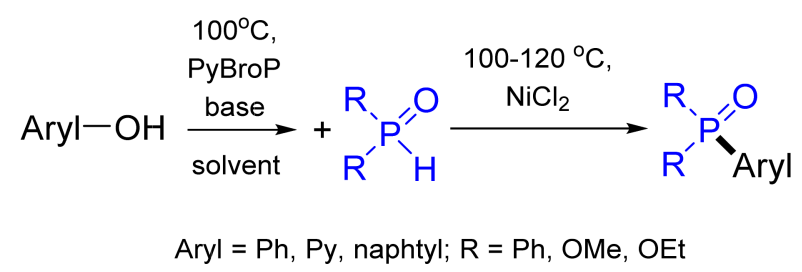

Figure 34. Hirao reaction after activating the hydroxyl group of phenols.

The substrate scope is further expanded for the coupling of aryl mesylates with dimethylphosphite and diphenylphosphane oxide utilizing $\mathrm{NiCl}_{2}(\mathrm{dppf}) / \mathrm{dppf}$ at $100{ }^{\circ} \mathrm{C}$ in the presence of diisopropylamine and zinc [84]. Later, the decarboxylative coupling of alkenyl acids with $H$-phosphonates was shown to obtain $(E)$-1-alkenylphosphonates (Figure 35) [106]. The reaction utilizes $\mathrm{NiCl}_{2}$ (dppf) with $\mathrm{Ag}_{2} \mathrm{O}$ at $100{ }^{\circ} \mathrm{C}$ under a nitrogen atmosphere. The substrate scope can be extended to the coupling of alkynyl acids to produce alkynyl phosphonates in moderate yields up to $92 \%$.

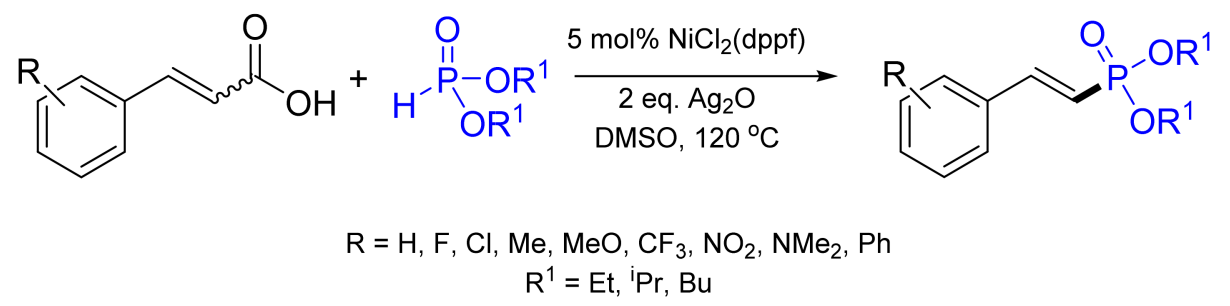

Figure 35. Decarboxylative cross-coupling of alkenyl acids with $\mathrm{P}(\mathrm{O}) \mathrm{H}$ compounds.

A catalytic deamidative phosphorylation of a wide range of amides using a Ni catalyst giving aryl phosphonates in good to excellent yields was reported (Figure 36) [107]. This method tolerates a wide range of functional groups. The reaction constitutes the first example of the transition metal-catalyzed generation of a C-P bond from amides. 


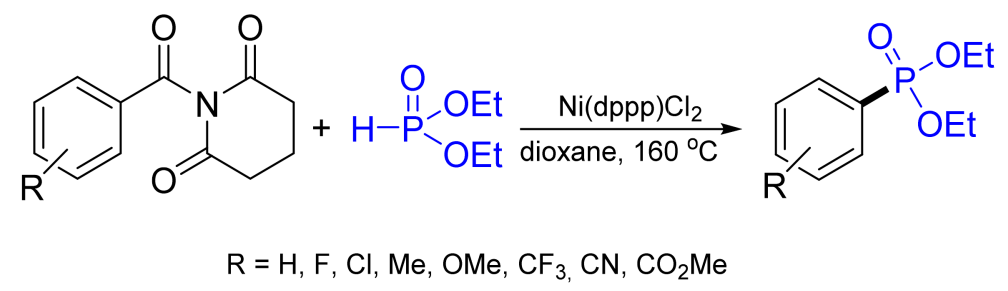

Figure 36. Phosphorylation of amides using Ni catalyst.

Keglevich and co-workers found that $\mathrm{NiCl}_{2}$ may also be a suitable catalyst in the microwave-assisted C-P coupling of bromobenzene and different $>\mathrm{P}(\mathrm{O}) \mathrm{H}$ species [108]. The experiments were carried out at $150{ }^{\circ} \mathrm{C}$ under $\mathrm{MW}$ irradiation, applying $\mathrm{K}_{2} \mathrm{CO}_{3}$ in the absence of any solvent with $68-92 \%$ (Figure 37). The $\mathrm{NiCl}_{2}$-catalyzed phosphonylation of substituted bromoarenes led to similar results as in the presence of $\mathrm{Pd}(\mathrm{OAc})_{2}$, but the scope of the aryl bromides was somewhat limited.

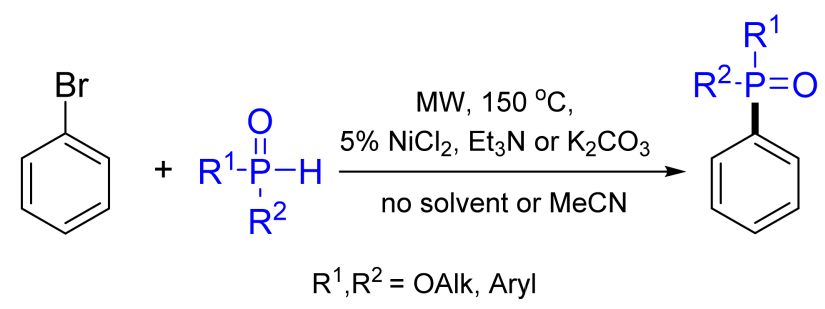

Figure 37. $\mathrm{NiCl}_{2}$-catalyzed phosphonylation.

Taking into account the reaction conditions, costs and safety concerns, it can be concluded that the application of $\mathrm{Pd}(\mathrm{OAc})_{2}$ is favorable, but the use of $\mathrm{NiCl}_{2}$ can also be a good alternative. Moreover, the $\mathrm{C}-\mathrm{P}$ coupling reactions which apply $\mathrm{Ni}(\mathrm{II})$ salts in the absence of reductants have been investigated earlier, including theoretical calculations $[109,110]$. These latest developments of Hirao coupling mean a big step forward to "P-ligand-free" catalytic reactions, since there is no need for sensitive and expensive $P$-ligands.

Recently, Budnikova and co-workers have demonstrated the possibility of the electrochemical phosphorylation of aromatic compounds (benzene and coumarins [111], pyridines [112], azoles [113]) with dialkyl phosphites (Figure 38). This novel approach is based on the oxidation of a mixture of the aromatic compound and diethyl phosphite (1:1) under mild electrochemical conditions (room temperature, atmospheric pressure) in the presence of bimetallic catalytic systems: $1 \%$ of $\mathrm{Mn}(\mathrm{II})(\mathrm{bpy}) / \mathrm{Ni}\left(\mathrm{BF}_{4}\right)(\mathrm{bpy})$. This method allows one to obtain diethyl arylphosphonates in good yields (up to $70 \%$ ) and 100\% conversion of the phosphite [114].

$$
\begin{aligned}
& 2 \mathrm{e}, 25^{\circ} \mathrm{C} \\
& \text { (1\%) }\left[\mathrm{MnCl}_{2}(\mathrm{bpy}) / \mathrm{Ni}\left(\mathrm{BF}_{4}\right)_{2}(\mathrm{bpy})\right. \\
& -2 \mathrm{H}^{+} \\
& \text {Alk }=\mathrm{Et},{ }^{\mathrm{i}} \mathrm{Pr},{ }^{\mathrm{n}} \mathrm{Bu} \\
& \text { Aryl = benzene, coumarines, benzonitrile, } N, N \text {-dimethylaniline, nitrobenzene }
\end{aligned}
$$

Figure 38. Phosphorylation of aromatic compounds in electrochemical conditions.

\section{Summary and Outlook}

C-P cross-coupling reactions have made significant progress in recent years. Although Pd-catalyzed reactions dominate, Ni-based catalytic systems have been considerably explored. This article may give a good overview on the present state of the art of the Nicatalyzed synthesis of racemic and scalemic phosphanes, phosphonium salts, phosphane oxides and phosphorus acid derivatives. Additionally, some green chemical approaches, such as MW activation, solvent- and reducing agent-free and electrochemical methods, 
have been outlined. The renaissance in nickel catalysis has brought new life to well-known nickel salts $\mathrm{NiX}_{2}(\mathrm{X}=\mathrm{Cl}, \mathrm{Br}, \mathrm{OAc}$, acac, etc.), which have been used as catalyst precursors. Solubility in organic solvents and the easy transformation of $\mathrm{Ni}(\mathrm{acac})_{2}$ to the catalyst active form ensure important preferences for practical applications.

The increasing price of $\mathrm{Pd}, \mathrm{Pt}$ and other noble metals even further stimulates the search for inexpensive and easily available Ni-based catalysts. Although the field of nickel catalysis has rapidly expanded over the last decade, there are many challenges that remain to be overcome. Nickel catalysts retain significant synthetic potential, are very reactive and design/control of their catalytic systems requires much more effort. Indeed, in the majority of known Ni-mediated reactions, the active catalyst remains unknown. We expect to see further developments in the area of Ni-catalyzed C-P bond formation, particularly in the expansion of substrate scope and the development of low-cost, air-stable and easy-to-handle sources of nickel for catalysis.

Author Contributions: Conceptualization and methodology, A.A.Z., I.F.S., V.A.M. and D.G.Y.; writing-original draft preparation, A.A.Z. and I.F.S.; writing—review and editing, V.A.M. and D.G.Y. All authors have read and agreed to the published version of the manuscript.

Funding: This research activity was funded by the Government assignment for FRC Kazan Scientific Center of RAS.

Data Availability Statement: Not applicable.

Conflicts of Interest: The authors declare no conflict of interest.

$\begin{array}{ll}\text { Abbreviations } & \\ \text { Ac } & \text { acetyl radical } \\ \text { acac } & \text { acetylacetone } \\ \text { BDPP } & (2 S, 4 S) \text {-2,4-bis(diphenylphosphino)pentane } \\ \text { BINAP } & \text { 2,2'-bis(diphenylphosphino)-1,1'-binaphthyl } \\ \text { bpy } & \text { 2,2'-bipyridine } \\ \text { BSA } & \text { bis(trimethylsilyl)acetamide } \\ \text { DABCO } & \text { 1,4-diazabicyclo [2.2.2]octane } \\ \text { DCE } & \text { 1,2-dichloroethane } \\ \text { dcypt } & \text { bis(dicyclohexylphosphano)thiophene } \\ \text { DIPEA } & \text { diethylisopropylamine } \\ \text { DME } & \text { 1,2-dimethoxyethane } \\ \text { DMF } & \text { N,N-dimethylformamide } \\ \text { Dmp } & \text { 2,6-dimesitylphenyl radical } \\ \text { dppe } & \text { 1,2-bis(diphenylphosphano)ethane } \\ \text { dppf } & \text { 1,1'-bis(diphenylphosphino)ferrocene } \\ \text { dppp } & \text { 1,3-bis(diphenylphosphano)propane). } \\ \text { dtbpe } & \text { 1,2-bis(di-tert-butylphosphino)ethane } \\ \text { MW irradiation } & \text { microwave irradiation } \\ \text { naphthyl } & \text { naphthyl radical } \\ \text { NMP } & \text { N-methyl-2-pyrrolidone } \\ \text { Pigiphos } & \text { bis }\{(R)-1-[(S) \text {-2-(diphenylphosphino)ferrocenyl]ethyl }\} \text { cyclohexylphosphane) } \\ \text { PINAP } & \text { (R)-(+)-4-[2-(diphenylphosphino)-1-naphthalenyl]- } N \text {-[-1-phenylethyl]-1- } \\ & \text { phthalazinamine } \\ \text { Py } & \text { pyridine } \\ \text { PyBroP } & \text { bromotripyrrolidinophosphonium hexafluorophosphate } \\ & \end{array}$

\section{References}

1. Allen, D.W. Phosphines and related C-P bonded compounds. Organophosphorus Chem. 2016, 45, 1-50. [CrossRef]

2. Peruzzini, M.; Gonsalvi, L. Phosphorus Compounds: Advanced Tools in Catalysis and Material Sciences; Springer: Dordrecht, The Netherlands, 2011.

3. Borner, A. Phosphorus Ligands in Asymmetric Catalysis; Wiley: Weinheim, Germany, 2008.

4. Rodriguez, J.B.; Gallo-Rodriguez, C. The role of the phosphorus atom in drug design. ChemMedChem 2018, 14, 190-216. [CrossRef] 
5. Zagidullin, A.A.; Bezkishko, I.A.; Miluykov, V.A.; Sinyashin, O.G. Phospholes-development and recent advances. Mendeleev Commun. 2013, 23, 117-130. [CrossRef]

6. Schwan, A. Palladium catalyzed cross-coupling reactions for phosphorus-carbon bond formation. Chem. Soc. Rev. 2004, 33, 218-224. [CrossRef]

7. Oestreich, M.; Tappe, F.; Trepohl, V. Transition-Metal-Catalyzed C-P Cross-Coupling Reactions. Synthesis 2010, $2010,3037-3062$. [CrossRef]

8. Wauters, I.; Debrouwer, W.; Stevens, C.V. Preparation of phosphines through C-P bond formation. Beilstein J. Org. Chem. 2014, 10, 1064-1096. [CrossRef]

9. Koshti, V.; Gaikwad, S.; Chikkali, S.H. Contemporary avenues in catalytic PH bond addition reaction: A case study of hydrophosphination. Coord. Chem. Rev. 2014, 265, 52-73. [CrossRef]

10. Tasker, S.Z.; Standley, E.A.; Jamison, T.F. Recent advances in homogeneous nickel catalysis. Nat. Cell Biol. 2014, 509, 299-309. [CrossRef]

11. Henrion, M.; Ritleng, V.; Chetcuti, M.J. Nickel N-Heterocyclic Carbene-Catalyzed C-C Bond Formation: Reactions and Mechanistic Aspects. ACS Catal. 2015, 5, 1283-1302. [CrossRef]

12. Trotuş, I.-T.; Zimmermann, T.; Schüth, F. Catalytic reactions of acetylene: A feedstock for the chemical industry revisited. Chem. Rev. 2013, 114, 1761-1782. [CrossRef]

13. Ananikov, V. Nickel: The "Spirited Horse" of Transition Metal Catalysis. ACS Catal. 2015, 5, 1964-1971. [CrossRef]

14. Cristau, H.-J.; Chêne, A.; Christol, H. Arylation catalytique d'organophosphorés. Produits de l'arylation, catalysée par les sels de nickel (II), de composés du phosphore tricoordiné. J. Organomet. Chem. 1980, 185, 283-295. [CrossRef]

15. Ager, D.J.; Laneman, S.A. Convenient and direct preparation of tertiary phosphines via nickel-catalysed cross-coupling. Chem. Commun. 1997, 2359-2360. [CrossRef]

16. Le Gall, E.; Troupel, M.; Nédélec, J.-Y. Nickel-catalyzed reductive coupling of chlorodiphenylphosphine with aryl bromides into functionalized triarylphosphines. Tetrahedron 2003, 59, 7497-7500. [CrossRef]

17. Sun, M.; Zang, Y.-S.; Hou, L.-K.; Chen, X.-X.; Sun, W.; Yang, S.-D. Convenient Formation of Triarylphosphines by Nickel-Catalyzed C-P Cross-Coupling with Aryl Chlorides. Eur. J. Org. Chem. 2014, 2014, 6796-6801. [CrossRef]

18. Beletskaya, I.P.; Afanasiev, V.V.; Kazankova, M.A.; Efimova, I.V. New Approach to Phosphinoalkynes Based on Pd- and NiCatalyzed Cross-Coupling of Terminal Alkynes with Chlorophosphanes. Org. Lett. 2003, 5, 4309-4311. [CrossRef]

19. Di Credico, B.; De Biani, F.F.; Gonsalvi, L.; Guerri, A.; Ienco, A.; Laschi, F.; Peruzzini, M.; Reginato, G.; Rossin, A.; Zanello, P. Cyclopentadienyl ruthenium(II) complexes with bridging alkynylphosphine ligands: Synthesis and electrochemical studies. Chem. Eur. J. 2009, 15, 11985-11998. [CrossRef] [PubMed]

20. Beletskaya, I.P.; Afanasiev, V.V.; Kazankova, M.A.; Efimova, I.V.; Antipin, M.U. A convenient and direct route to phosphinoalkynes via copper-catalyzed cross-coupling of terminal alkynes with chlorophosphanes. Synthesis 2003, 2003, 2835-2838. [CrossRef]

21. Kazankova, M.A.; Shulyupin, M.O.; Chirkov, E.A.; Beletskaya, I.P. Nickel-catalyzed cross-coupling of diphenylphosphine with vinyl bromides and chlorides as a route to diphenylvinylphosphines. Synlett 2005, 2005, 658-660. [CrossRef]

22. Beletskaya, I.; Kazankova, M.A. Catalytic methods for building up phosphorus-carbon bond. Russ. J. Org. Chem. 2002, 38, 1391-1430. [CrossRef]

23. Trostyanskaya, I.G.; Titskiy, D.Y.; Anufrieva, E.A.; Borisenko, A.A.; Kazankova, M.A.; Beletskaya, I.P. Cross-coupling of E,E-1,4diiodobuta-1,3-diene with nucleophiles catalyzed by Pd or Ni complexes: A new route to functionalized dienes. Russ. Chem. Bull. 2001, 50, 2095-2100. [CrossRef]

24. Berthod, M.; Mignani, G.; Woodward, G.; Lemaire, M. Modified BINAP: The how and the why. Chem. Rev. 2005, 105, 1801-1836. [CrossRef]

25. Cai, D.; Payack, J.F.; Bender, D.R.; Hughes, D.L.; Verhoeven, T.R.; Reider, P.J. Synthesis of Chiral 2,2'-Bis(diphenylphosphino)-1,1'binaphthyl (BINAP) via a Novel Nickel-Catalyzed Phosphine Insertion. J. Org. Chem. 1994, 59, 7180-7181. [CrossRef]

26. Kerrigan, N.J.; Dunne, E.C.; Cunningham, D.; McArdle, P.; Gilligan, K.; Gilheany, D.G. Studies in the preparation of novel P-chirogenic binaphthyl monophosphanes (MOPs). Tetrahedron Lett. 2003, 44, 8461-8465. [CrossRef]

27. Morris, D.J.; Docherty, G.; Woodward, G.; Wills, M. Modification of ligand properties of phosphine ligands for C-C and C-N bond-forming reactions. Tetrahedron Lett. 2007, 48, 949-953. [CrossRef]

28. Fleming, W.J.; Müller-Bunz, H.; Lillo, V.; Fernandez, E.; Guiry, P.J. Axially chiral P-N ligands for the copper catalyzed $\beta$-borylation of $\alpha, \beta$-unsaturated esters. Org. Biomol. Chem. 2009, 7, 2520-2524. [CrossRef]

29. Fleming, W.J.; Müller-Bunz, H.; Guiry, P.J. Synthesis and post-resolution modification of new axially chiral ligands for asymmetric catalysis. Eur. J. Org. Chem. 2010, 2010, 5996-6004. [CrossRef]

30. Rafter, E.; Muldoon, J.; Bunz, H.M.; Gilheany, D.G. Synthesis of P-stereogenic BINAP bissulfide analogues. Tetrahedron Asymmetry 2011, 22, 1680-1686. [CrossRef]

31. Pereira, M.M.; Calvete, M.J.F.; Carrilho, R.M.B.; Abreu, A.R. Synthesis of binaphthyl based phosphine and phosphite ligands. Chem. Soc. Rev. 2013, 42, 6990-7027. [CrossRef]

32. Enev, V.; Ewers, C.L.J.; Harre, M.; Nickisch, K.; Mohr, J.T. A Bis-steroidal phosphine as new chiral hydrogenation ligand. J. Org. Chem. 1997, 62, 7092-7093. [CrossRef]

33. Lacey, P.M.; McDonnell, C.M.; Guiry, P.J. Synthesis and resolution of 2-methyl-Quinazolinap, a new atropisomeric phosphinamine ligand for asymmetric catalysis. Tetrahedron Lett. 2000, 41, 2475-2478. [CrossRef] 
34. Knöpfel, T.F.; Aschwanden, P.; Ichikawa, T.; Watanabe, T.; Carreira, E.M. Readily Available Biaryl P,N Ligands for Asymmetric Catalysis. Angew. Chem. Int. Ed. 2004, 43, 5971-5973. [CrossRef] [PubMed]

35. Knöpfel, T.F.; Zarotti, P.; Ichikawa, T.; Carreira, E. Catalytic, enantioselective, conjugate alkyne addition. J. Am. Chem. Soc. 2005, 127, 9682-9683. [CrossRef]

36. Birdsall, D.J.; Hope, E.G.; Stuart, A.M.; Chen, W.; Hu, Y.; Xiao, J. Synthesis of fluoroalkyl-derivatised BINAP ligands. Tetrahedron Lett. 2001, 42, 8551-8553. [CrossRef]

37. Nakamura, Y.; Takeuchi, S.; Zhang, S.; Okumura, K.; Ohgo, Y. Preparation of a fluorous chiral BINAP and application to an asymmetric Heck reaction. Tetrahedron Lett. 2002, 43, 3053-3056. [CrossRef]

38. Zhao, Y.-L.; Wu, G.-J.; Li, Y.; Gao, L.-X.; Han, F.-S. [NiCl 2 (dppp)]-catalyzed cross-coupling of aryl halides with dialkyl phosphite, diphenylphosphine oxide, and diphenylphosphine. Chem. Eur. J. 2012, 18, 9622-9627. [CrossRef]

39. Klein, A.; Budnikova, Y.H.; Sinyashin, O. Electron transfer in organonickel complexes of $\alpha$-diimines: Versatile redox catalysts for C-C or C-P coupling reactions-A review. J. Organomet. Chem. 2007, 692, 3156-3166. [CrossRef]

40. Budnikova, Y.H.; Perichon, J.; Yakhvarov, D.G.; Kargin, Y.M.; Sinyashin, O. Highly reactive $\sigma$-organonickel complexes in electrocatalytic processes. J. Organomet. Chem. 2001, 630, 185-192. [CrossRef]

41. Yakhvarov, D.G.; Khusnuriyalova, A.F.; Sinyashin, O. Electrochemical synthesis and properties of organonickel $\sigma$-complexes. Organometallics 2014, 33, 4574-4589. [CrossRef]

42. Yakhvarov, D.G.; Kvashennikova, S.V.; Sinyashin, O. Reactions of activated organonickel $\sigma$-complexes with elemental (white) phosphorus. Russ. Chem. Bull. 2013, 62, 2472-2476. [CrossRef]

43. Gafurov, Z.; Musin, L.; Sakhapov, I.F.; Babaev, V.; Musina, E.I.; Karasik, A.A.; Sinyashin, O.; Yakhvarov, D.G. The formation of secondary arylphosphines in the reaction of organonickel sigma-complex [NiBr(Mes)(bpy)], where Mes = 2,4,6-trimethylphenyl, bpy = 2,2'-bipyridine, with phenylphosphine. Phosphorus Sulfur Silicon Relat. Elements 2016, 191, 1475-1477. [CrossRef]

44. Gafurov, Z.; Sakhapov, I.F.; Kagilev, A.A.; Kantyukov, A.O.; Khayarov, K.R.; Sinyashin, O.; Yakhvarov, D.G. The formation of mesitylphosphine and dimesitylphosphine in the reaction of organonickel $\sigma$-complex $[\mathrm{NiBr}(\mathrm{Mes})(\mathrm{bpy})](\mathrm{Mes}=2,4,6-$ trimethylphenyl, bpy =2,2'-bipyridine) with phosphine PH3. Phosphorus Sulfur Silicon Relat. Elements 2020, 195, 726-729. [CrossRef]

45. Bange, C.A.; Waterman, R. Challenges in Catalytic Hydrophosphination. Chem. Eur. J. 2016, 22, 12598-12605. [CrossRef]

46. Kazankova, M.A.; Shulyupin, M.O.; Borisenko, A.A.; Beletskaya, I. Synthesis of alkyl(diphenyl)phosphines by hydrophosphination of vinylarenes catalyzed by transition metal complexes. Russ. J. Org. Chem. 2002, 38, 1479-1484. [CrossRef]

47. Beletskaya, I.P.; Kazankova, M.A.; Shulyupin, M.O. Catalytic Hydrophosphination of Alkenylalkyl Ethers. Synlett 2003, 2003, 2155-2158. [CrossRef]

48. Ananikov, V.; Gayduk, K.A.; Starikova, Z.A.; Beletskaya, I. Ni(acac) 2 /phosphine as an excellent precursor of Nickel(0) for catalytic systems. Organometallics 2010, 29, 5098-5102. [CrossRef]

49. Webster, R.L. Room Temperature Ni(II) Catalyzed Hydrophosphination and Cyclotrimerization of Alkynes. Inorganics 2018, 6, 120. [CrossRef]

50. Shulyupin, M.O.; Kazankova, M.A.; Beletskaya, I. Catalytic Hydrophosphination of Styrenes. Org. Lett. 2002, 4, 761-763. [CrossRef]

51. Ganushevich, Y.S.; Miluykov, V.A.; Polyancev, F.M.; Latypov, S.; Lönnecke, P.; Hey-Hawkins, E.; Yakhvarov, D.G.; Sinyashin, O. Nickel Phosphanido Hydride Complex: An Intermediate in the Hydrophosphination of Unactivated Alkenes by Primary Phosphine. Organometallics 2013, 32, 3914-3919. [CrossRef]

52. Latypov, S.K.; Kondrashova, S.A.; Polyancev, F.M.; Sinyashin, O.G. Quantum Chemical Calculations of 31P NMR Chemical Shifts in Nickel Complexes: Scope and Limitations. Organometallics 2020, 39, 1413-1422. [CrossRef]

53. Latypov, S.K.; Polyancev, F.M.; Ganushevich, Y.S.; Miluykov, V.A.; Sinyashin, O.G. Mechanism of intramolecular transformations of nickel phosphanido hydride complexes. Dalton Trans. 2015, 45, 2053-2059. [CrossRef]

54. Wang, C.; Huang, K.; Ye, J.; Duan, W.-L. Asymmetric Synthesis of P-Stereogenic Secondary Phosphine-Boranes by an Unsymmetric Bisphosphine Pincer-Nickel Complex. J. Am. Chem. Soc. 2021, 143, 5685-5690. [CrossRef]

55. Sadow, A.D.; Haller, I.; Fadini, A.L.; Togni, A. Nickel(II)-Catalyzed Highly Enantioselective Hydrophosphination of Methacrylonitrile. J. Am. Chem. Soc. 2004, 126, 14704-14705. [CrossRef] [PubMed]

56. Sadow, A.D.; Togni, A. Enantioselective addition of secondary phosphines to methacrylonitrile: Catalysis and mechanism. J. Am. Chem. Soc. 2005, 127, 17012-17024. [CrossRef]

57. Kazankova, M.A.; Efimova, I.V.; Kochetkov, A.N.; Afanas'Ev, V.V.; Beletskaya, I.; Dixneuf, P.H. New Approach to Vinylphosphines Based on Pd- and Ni-Catalyzed Diphenylphosphine Addition to Alkynes. Synlett 2001, 2001, 0497-0500. [CrossRef]

58. Kazankova, M.A.; Efimova, I.V.; Kochetkov, A.; Afanas'Ev, V.V.; Beletskaya, I.P. Synthesis of Vinylphosphines by Hydrophosphination of Alkynes in the Presence of Transition Metal Complexes. Russ. J. Org. Chem. 2002, 38, 1465-1474. [CrossRef]

59. Ananikov, V.P.; Beletskaya, I. Alkyne insertion into the $\mathrm{M}-\mathrm{P}$ and $\mathrm{M}-\mathrm{H}$ bonds ( $\mathrm{M}=\mathrm{Pd}, \mathrm{Ni}$, $\mathrm{Pt}$, and $\mathrm{Rh})$ : A theoretical mechanistic study of the C-P and C-H bond-formation steps. Chem. Asian J. 2011, 6, 1423-1430. [CrossRef]

60. Yan, J.; Wang, Y.; Hou, S.; Shi, L.; Zhu, X.; Hao, X.; Song, M. NCC Pincer Ni (II) complexes Catalyzed hydrophosphination of Nitroalkenes with diphenylphosphine. Appl. Organomet. Chem. 2020, 34, 5954. [CrossRef]

61. Ribiere, P.; Bravo-Altamirano, K.; Antczak, M.I.; Hawkins, J.D.; Montchamp, J.-L. $\mathrm{NiCl}_{2}$-Catalyzed Hydrophosphinylation. J. Org. Chem. 2005, 70, 4064-4072. [CrossRef] 
62. Ananikov, V.; Khemchyan, L.L.; Beletskaya, I.; Starikova, Z.A. Acid-Free Nickel Catalyst for Stereo- and Regioselective Hydrophosphorylation of Alkynes: Synthetic Procedure and Combined Experimental and Theoretical Mechanistic Study. Adv. Synth. Catal. 2010, 352, 2979-2992. [CrossRef]

63. Han, L.-B.; Ono, Y.; Yazawa, H. Nickel-Catalyzed Addition of $\mathrm{P}(\mathrm{O})-\mathrm{H}$ Bonds to Propargyl Alcohols: One-Pot Generation of Phosphinoyl 1,3-Butadienes. Org. Lett. 2005, 7, 2909-2911. [CrossRef]

64. Han, L.-B.; Zhang, C.; Yazawa, A.H.; Shimada, S. Efficient and Selective Nickel-Catalyzed Addition of H-P(O) and H-S Bonds to Alkynes. J. Am. Chem. Soc. 2004, 126, 5080-5081. [CrossRef]

65. Cassar, L.; Foà, M. Nickel-catalyzed synthesis of phosphonium salts. J. Organomet. Chem. 1974, 74, 75. [CrossRef]

66. Allen, D.W.; Coles, S.J.; Light, M.E.; Hursthouse, M.B. Synthesis and X-ray crystal structures of organotri(2-furyl)phosphonium salts: Effects of 2-furyl substituents at phosphorus on intramolecular nitrogen to phosphorus hypervalent coordinative interactions. Inorganica Chim. Acta 2004, 357, 1558-1564. [CrossRef]

67. Monkowius, U.V.; Nogai, S.; Schmidbaur, H. Unsuccessful/successful attempts to produce penta(heteroaryl)-phosphoranes/arsoranes R5E (E = P, As; R = 2-furyl, 2-thienyl). Dalton Trans. 2004, 10, 1610-1617. [CrossRef] [PubMed]

68. Asay, M.; Donnadieu, B.; Baceiredo, A.; Soleilhavoup, M.; Bertrand, G. Cyclic (Amino)[bis(ylide)]carbene as an Anionic Bidentate Ligand for Transition-Metal Complexes. Inorg. Chem. 2008, 47, 3949-3951. [CrossRef] [PubMed]

69. Manabe, K. Synthesis of novel chiral quaternary phosphonium salts with a multiple hydrogen-bonding site, and their application to asymmetric phase-transfer alkylation. Tetrahedron 1998, 54, 14465-14476. [CrossRef]

70. Marcoux, D.; Charette, A.B. Nickel-Catalyzed Synthesis of Phosphonium Salts from Aryl Halides and Triphenylphosphine. Adv. Synth. Catal. 2008, 350, 2967-2974. [CrossRef]

71. Wan, W.; Yang, X.; Smith, R.C. Convenient route to tetraarylphosphonium polyelectrolytes via metal-catalysed P-C coupling polymerisation of aryl dihalides and diphenylphosphine. Chem. Commun. 2016, 53, 252-254. [CrossRef]

72. Budnikova, Y.H.; Sinyashin, O.G.; Budnikova, Y.H. Phosphorylation of C-H bonds of aromatic compounds using metals and metal complexes. Russ. Chem. Rev. 2015, 84, 917-951. [CrossRef]

73. Zhang, H.-Y.; Sun, M.; Ma, Y.-N.; Tian, Q.-P.; Yang, S.-D. Nickel-catalyzed C-P cross-coupling of diphenylphosphine oxide with aryl chlorides. Org. Biomol. Chem. 2012, 10, 9627-9633. [CrossRef]

74. Zhang, X.; Liu, H.; Hu, X.; Tang, G.; Zhu, J.; Zhao, Y. Ni(II)/Zn Catalyzed Reductive Coupling of Aryl Halides with Diphenylphosphine Oxide in Water. Org. Lett. 2011, 13, 3478-3481. [CrossRef]

75. Hu, G.; Chen, W.; Fu, T.; Peng, Z.; Qiao, H.; Gao, Y.; Zhao, Y. Nickel-Catalyzed C-P Cross-Coupling of Arylboronic Acids with $\mathrm{P}(\mathrm{O}) \mathrm{H}$ Compounds. Org. Lett. 2013, 15, 5362-5365. [CrossRef]

76. Liu, L.L.; Wang, Y.; Zeng, Z.; Xu, P.; Gao, Y.; Yin, Y.; Zhao, Y. Nickel(II)-Magnesium-Catalyzed Cross-Coupling of 1,1-Dibromo-1alkenes with Diphenylphosphine Oxide: One-Pot Synthesis of (E)-1-Alkenylphosphine Oxides or Bisphosphine Oxides. Adv. Synth. Catal. 2013, 355, 659-666. [CrossRef]

77. Xuan, J.; Zeng, T.-T.; Chen, J.-R.; Lu, L.-Q.; Xiao, W.-J. Room Temperature C-P Bond Formation Enabled by Merging Nickel Catalysis and Visible-Light-Induced Photoredox Catalysis. Chem. Eur. J. 2015, 21, 4962-4965. [CrossRef]

78. Isshiki, R.; Muto, K.; Yamaguchi, J. Decarbonylative C-P Bond Formation Using Aromatic Esters and Organophosphorus Compounds. Org. Lett. 2018, 20, 1150-1153. [CrossRef]

79. Liu, X.-T.; Zhang, Y.-Q.; Han, X.-Y.; Sun, S.-P.; Zhang, Q.-W. Ni-Catalyzed Asymmetric Allylation of Secondary Phosphine Oxides. J. Am. Chem. Soc. 2019, 141, 16584-16589. [CrossRef]

80. Hou, H.; Zhou, B.; Wang, J.; Sun, D.; Yu, H.; Chen, X.; Han, Y.; Shi, Y.; Yan, C.; Zhu, S. Visible-light-induced ligand to metal charge transfer excitation enabled phosphorylation of aryl halides. Chem. Commun. 2021, 57, 5702-5705. [CrossRef]

81. Łastawiecka, E.; Flis, A.; Stankevič, M.; Greluk, M.; Słowik, G.; Gac, W. P-Arylation of secondary phosphine oxides catalyzed by nickel-supported nanoparticles. Org. Chem. Front. 2018, 5, 2079-2085. [CrossRef]

82. Balthazor, T.M. Phosphindolin-3-one. A useful intermediate for phosphindole synthesis. J. Org. Chem. 1980, 45, $2519-2522$. [CrossRef]

83. Hirao, T.; Masunaga, T.; Ohshiro, Y.; Agawa, T. Stereoselective synthesis of vinylphosphonate. Tetrahedron Lett. 1980, 21, 3595-3598. [CrossRef]

84. Shen, C.; Yang, G.; Zhang, W. Nickel-catalyzed C-P coupling of aryl mesylates and tosylates with H(O)PR1R2. Org. Biomol. Chem. 2012, 10, 3500-3505. [CrossRef]

85. Tavs, P. Reaktion von Arylhalogeniden mit Trialkylphosphiten und Benzolphosphonigsäure-Dialkylestern zu Aromatischen Phosphonsäureestern und Phosphinsäureestern unter Nickelsalzkatalyse. Eur. J. Inorg. Chem. 1970, 103, 2428-2436. [CrossRef]

86. Tavs, P.; Weitkamp, H. Herstellung und KMR-spektren einiger $\alpha, \beta$-ungesättigter phosphonsäureester: Nickelsalzkatalysierte reaktion von vinylhalogeniden mit trialkylphosphiten. Tetrahedron 1970, 26, 5529-5534. [CrossRef]

87. Comins, D.L.; Ollinger, C.G. Inter- and intramolecular Horner-Wadsworth-Emmons reactions of 5-(diethoxyphosphoryl)-1-acyl2-alkyl(aryl)-2,3-dihydro-4-pyridones. Tetrahedron Lett. 2001, 42, 4115-4118. [CrossRef]

88. DeMik, N.N.; Kabachnik, M.M.; Novikova, Z.S.; Beletskaya, I.P. Preparation of arylphosphonates by the reaction of aryl halides with tris(trimethylsilyl) phosphite under homogeneous catalysis conditions. Russ. Chem. Bull. 1991, 40, 1300-1301. [CrossRef]

89. Kazankova, M.A.; Trostyanskaya, I.G.; Lutsenko, S.V.; Efimova, I.V.; Beletskaya, I.P. Synthesis of 1- and 2-alkoxy- and dialkylaminoalkenyl-phosphonates, catalyzed by transition metal complexes. Russ. J. Org. Chem. 1999, 35, 452-458. 
90. Kazankova, M.A.; Trostyanskaya, I.G.; Lutsenko, S.V.; Beletskaya, I. Nickel- and palladium-catalyzed cross-coupling as a route to 1- and 2-alkoxy- or dialkylaminovinylphosphonates. Tetrahedron Lett. 1999, 40, 569-572. [CrossRef]

91. Balthazor, T.M.; Grabiak, R.C. Nickel-catalyzed Arbuzov reaction: Mechanistic observations. J. Org. Chem. 1980, 45, 5425-5426. [CrossRef]

92. Heinicke, J.; Gupta, N.; Surana, A.; Peulecke, N.; Witt, B.; Steinhauser, K.; Bansal, R.K.; Jones, P.G. Synthesis of 1H-1,3benzazaphospholes: Substituent influence and mechanistical aspects. Tetrahedron 2001, 57, 9963-9972. [CrossRef]

93. Yang, G.; Shen, C.; Zhang, L.; Zhang, W. Nickel-catalyzed Arbuzov reactions of aryl triflates with triethyl phosphite. Tetrahedron Lett. 2011, 52, 5032-5035. [CrossRef]

94. Hirao, T.; Masunaga, T.; Yamada, N.; Ohshiro, Y.; Agawa, T. Palladium-catalyzed New Carbon-Phosphorus Bond Formation. Bull. Chem. Soc. Jpn. 1982, 55, 909-913. [CrossRef]

95. Lu, X.; Zhu, J. Nickel(0)-catalyzed Reaction of O,O-Dialkyl Phosphonates with Allyl Acetates or Carbonates. A Novel Method of Preparing Allyl Phosphonates. Synthesis 1986, 1986, 563-564. [CrossRef]

96. Lu, X.; Tao, X.; Zhu, J.; Sun, X.; Xu, J. Regio- and Stereoselective Synthesis of Symmetrical and Unsymmetrical 1,3Diphosphoryl(Phosphonyl, Phosphinyl) Substituted (E)-Propenes. Synthesis 1989, 1989, 848-850. [CrossRef]

97. Yang, J.; Xiao, J.; Chen, T.; Han, L.-B. Nickel-catalyzed phosphorylation of aryl triflates with $\mathrm{P}(\mathrm{O}) \mathrm{H}$ compounds. J. Organomet. Chem. 2016, 820, 120-124. [CrossRef]

98. Yang, J.; Chen, T.; Han, L.-B. C-P Bond-Forming Reactions via C-O/P-H Cross-Coupling Catalyzed by Nickel. J. Am. Chem. Soc. 2015, 137, 1782-1785. [CrossRef]

99. Yang, J.; Xiao, J.; Chen, T.; Han, L.-B. Nickel-Catalyzed Phosphorylation of Phenol Derivatives via C-O/P-H Cross-Coupling. J. Org. Chem. 2016, 81, 3911-3916. [CrossRef]

100. Liao, L.-L.; Gui, Y.-Y.; Zhang, X.-B.; Shen, G.; Liu, H.-D.; Zhou, W.-J.; Li-Li, L.; Yong-Yuan, G. Phosphorylation of Alkenyl and Aryl C-O Bonds via Photoredox/Nickel Dual Catalysis. Org. Lett. 2017, 19, 3735-3738. [CrossRef] [PubMed]

101. Yang, B.; Wang, Z.-X. Ni-Catalyzed C-P Coupling of Aryl, Benzyl, or Allyl Ammonium Salts with P(O)H Compounds. J. Org. Chem. 2019, 84, 1500-1509. [CrossRef]

102. Yang, J.; Xiao, J.; Chen, T.; Yin, S.-F.; Han, L.-B. Efficient nickel-catalyzed phosphinylation of C-S bonds forming C-P bonds. Chem. Commun. 2016, 52, 12233-12236. [CrossRef]

103. Zhang, J.-S.; Chen, T.; Yang, J.; Han, L.-B. Nickel-catalysed P-C bond formation via P-H/C-CN cross coupling reactions. Chem. Commun. 2015, 51, 7540-7542. [CrossRef]

104. Sun, M.; Zhang, H.-Y.; Han, Q.; Yang, K.; Yang, S.-D. Nickel-Catalyzed C-P Cross-Coupling by C-CN Bond Cleavage. Chem. A Eur. J. 2011, 17, 9566-9570. [CrossRef]

105. Zhao, Y.-L.; Wu, G.-J.; Han, F.-S. Ni-catalyzed construction of C-P bonds from electron-deficient phenols via the in situ aryl C-O activation by PyBroP. Chem. Commun. 2012, 48, 5868-5870. [CrossRef] [PubMed]

106. Wu, Y.; Liu, L.L.; Yan, K.; Xu, P.; Gao, Y.; Zhao, Y. Nickel-Catalyzed Decarboxylative C-P cross-coupling of alkenyl acids with $\mathrm{P}(\mathrm{O}) \mathrm{H}$ compounds. J. Org. Chem. 2014, 79, 8118-8127. [CrossRef] [PubMed]

107. Liu, C.; Szostak, M. Decarbonylative phosphorylation of amides by palladium and nickel catalysis: The Hirao cross-coupling of amide derivatives. Angew. Chem. Int. Ed. 2017, 56, 12718-12722. [CrossRef]

108. Jablonkai, E.; Balazs, L.; Keglevich, G. A P-ligand-free nickel-catalyzed variation of the hirao reaction under microwave conditions. Curr. Org. Chem. 2015, 19, 197-202. [CrossRef]

109. Keglevich, G.; Henyecz, R.; Mucsi, Z. Focusing on the Catal. of the Pd- and Ni-Catalyzed Hirao Reactions. Molecules 2020, 25, 3897. [CrossRef] [PubMed]

110. Henyecz, R.; Mucsi, Z.; Keglevich, G. A surprising mechanism lacking the Ni(0) state during the Ni(II)-catalyzed P-C crosscoupling reaction performed in the absence of a reducing agent-An experimental and a theoretical study. Pure Appl. Chem. 2020, 92, 493-503. [CrossRef]

111. Khrizanforov, M.; Strekalova, S.; Kholin, K.; Khrizanforova, V.; Kadirov, M.; Gryaznova, T.; Budnikova, Y. Novel approach to metal-induced oxidative phosphorylation of aromatic compounds. Catal. Today 2017, 279, 133-141. [CrossRef]

112. Strekalova, S.; Khrizanforov, M.; Sinyashin, O.; Budnikova, Y. Catalytic Phosphorylation of Aromatic C-H Bonds: From Traditional Approaches to Electrochemistry. Curr. Org. Chem. 2019, 23, 1756-1770. [CrossRef]

113. Gryaznova, T.V.; Khrizanforov, M.; Strekalova, S.O.; Budnikova, Y.H.; Sinyshin, O.G. Electrochemical oxidative phosphonation of azoles. Phosphorus Sulfur Silicon Relat. Elem. 2016, 191, 1658-1659. [CrossRef]

114. Budnikova, Y.H.; Gryaznova, T.V.; Grinenko, V.; Dudkina, Y.; Khrizanforov, M. Eco-efficient electrocatalytic C-P bond formation. Pure Appl. Chem. 2017, 89, 311-330. [CrossRef] 